\title{
Üretüketici Emeğin Metalaşması: Twitter Örneğinde Eleştirel Ekonomi Politik Bir Çözümleme
}

ERDAL DAĞTAŞ*

edagtas@anadolu.edu.tr

ORCID ID: 0000-0001-9716-2150

\author{
CEMGAZI YOLDAŞ** \\ gaziyoldas@gmail.com \\ ORCID ID: 0000-0003-0154-5814
}

Öz: Sosyal paylaşım sitesi Twitter'da çevrimiçi etkinliklerde bulunan kullanıııların metalaşma süreçlerini ve sömürülme biçimlerini ele alan bu çalışma, eleştirel ekonomi politik yaklaşım üzerine yükselmektedir. Son yillarda iletişim teknolojilerinde yaşanan gelişmelerle birlikte sosyal medyanın yükselişinin, kapitalist üretim tarzı içinde değerlendirilmesinin sunulduğu bu çalışmada, Twitter'da yer alan üretim ve değişim ilişkileri incelenmiştir. Twitter'da egemen olan kapitalist ilişki, süreç ve biçimler belirlenen tematik kategoriler altında değerlendirilirken; bu kategorilerde yapılan saptamalar Twitter kullanıcıları arasından amaçlı örneklem tekniğiyle oluşturulan 10 katılımcının bulunduğu örnek araştırma grubuyla yapılan yarı yapılandırılmış derinlemesine görüşmelerin değerlendirilmesiyle elde edilmiştir. Twitter’n katılımcılar tarafından içinde üretim ve değișim ilișkilerinin gerçekleștiği bir dijital mekân ve bu ilișkilerin gerçekleşmesine olanak sağlayan bir araç olarak görüldüğ̈̈ sonucuna ulaşılmıştır.

Anahtar kelimeler: Twitter, Üretüketici emeği, İzleyici metası, Metalaşma süreçleri, İlkel birikim

\section{Giriş}

Neo-liberal birikim düzeni, günümüz kapitalist ilişkilerinin belirleyici birikim mantığını oluşturmaktadır. 1980’li yıllardan itibaren birikim düzeninde yaşanan bu değişimin, sosyo-ekonomik ve toplumsal yaşam üzerinde etkileri bulunmaktadır. Batı dünyasının tanık olduğu bu değişimlerin en köklüsü kitle iletişim sistemi üzerinde yaşanan değişimlerdir. ${ }^{1}$ Öte yandan, yirmi birinci yüzyılın ilk yirmi yılında 1980'lerde kitle iletişim alanında yaşanan gelişmelere oranla daha köklü ve hızlı bir değişime tanıklık edilmiştir. Bunun en önemli nedeni ise yeni iletişim teknolojileri, internet ve bilişim sektörünün gelişimi ve dönüşümüdür.

Bu çalışma, Prof. Dr. Erdal Dağtaş่ın danışmanlığında Cemgazi Yoldaş tarafından 2020 yılında Üretüketici Emeğinin Metalaşmasının Twitter Örneğinde Çözümlenmesi başlığıyla sunularak kabul edilen yüksek lisans tezinden üretilmiştir.

* Prof., Dr., Anadolu Üniversitesi İletişim Bilimleri Fakültesi, Basın ve Yayın Bölümü.

** Bilim Uzmanı.

1 Ahmet Raşit Kaya, İktidar Yumağı, Ankara: İmge Kitapevi Yayınları, 2016, s.127. 
Yaşanan bu değişimin birikim düzeni değişimi olduğu ifade edilmelidir. Sermaye birikiminin krize girdiği zamanlarda, başka bir sermaye birikim düzenine geçiş ve bu geçişle birlikte artı değer elde edilecek alanların ve araçların değişimi kapitalist sistem için tarihsel olarak ne ilk ne de son defa gerçekleşmektedir. Kaldı ki, her birikim düzeninin temel mantığı ise aynı kalmaktadır. Bu mantık, sermaye birikiminin dolaşımının sağlanması ve sermaye birikiminin ençoklaştırılmasıdır. Dolayısıyla, iletişim alanında yaşanan değişim ve dönüşümler ele alınırken sermayenin bu temel mantığı unutulmamalıdır.

Enformasyon teknolojileri, kapitalist üretim ilişkileri çerçevesinde yeni birikim düzeninin bir parçası haline gelmiştir. Yeni iletişim teknolojileri ve yeni medya ele alınırken, yaklaşık 40 yıl önce kavramsallaştırılan izleyici metası tartışmasını günümüzde yeniden okumak bu gelişmeleri kapitalist sistem içinden algılamak için önemli olanaklar sunmaktadır. Dallas W. Smythe 1977'de kaleme aldığı Batı Marksizminin Kör Noktası başlıklı makalesinde, çalışma zamanı dışında da işçinin sermaye birikimine katkı sağladığı saptamasında bulunmuştur. ${ }^{2}$

Günümüzde, sosyal medya kullanıcılarının metalaşma süreçleri de benzer bir şekilde açıklanmaktadır. İnternet kullanıcısının metalaşması her şeyin metalaşması eğiliminin bir parçasıdır. İnternet ve sosyal medya, izleyici metasını yaygınlaştıran teknolojilerdir ve sömürünün geniş alanlara yayılmasına olanak sağlarken dünya ise kapitalist bir fabrikaya dönüşmektedir. ${ }^{3}$

Twitter Yatırımcı İlişkileri tarafından yayınlanan raporda, dünya üzerinde Twitter’’n 152 milyon kullanıcısının olduğu belirtilmektedir. Bu kullanıcıların 9 milyona yakını ise Türkiye'de bulunmaktadır. ${ }^{4}$ Twitter'da kullanıcılar, tweetler aracılığıla sosyal medya içeriği oluşturmakta ve dolaşıma sokmaktadır. Twitter'da yer alan reklamcılık faaliyetlerinin yanı sıra, kullanıcılar tarafından yapılan beğeni, retweet, mention gibi çevrimiçi etkinlikler platformun tıklanma sayısını arttırmakta ve şirkete kazanç sağlamaktadır. Öte yandan, bir tweetin 280 karakterle sınırlı olması, uzun metinlerin tek seferde paylaşımını olanaksız kılmaktadır. Bu haliyle, uzun metinlerin parçalara ayrılarak dolaşıma girmesi ve her paylaşımın ayrı bir etkileşim süreci içinde yer alması söz konusudur. Her bir etkileşim sürecinde, üretilen içerikler değer yaratım zinciri içinde metalar olarak yerini almaktadır. Ayrıca, çevrimiçi etkinlikte bulunan kullanıcılar, reklamverenlere satılan birer izleyici metası biçimini almaktadır. Twitter'daki izleyici metasının geleneksel medyadaki izleyici metasından farkı ise kullanıcıların içerik üreticisi olmasıdır. ${ }^{5}$

Vurgulanan bu noktalar çerçevesinde, insan emeğine yönelen sömürünün günümüzde kapitalist birikim düzeniyle birlikte ulaştığı boyutların ne olduğu, bu sömürünün sosyal medya aracılığıyla nasıl olanaklı kılındığı çalışmanın sorun ettiği

\footnotetext{
2 Dallas Walker Smythe, “Batı Marksizminin Kör Noktası”, Kitle İletişiminin Ekonomi Politiği, der., Levent Yaylagül, Ankara: Dalbaz Yayıncılık, 2006, s.127-172.

3 Christian Fuchs, Sosyal Medya: Eleştirel Bir Giriş, çev., İlker Kalaycı ve Diyar Saraçoğlu, İstanbul: NotaBene Yayınlar1, 2018, s.161-162.

4 Twitter Investor Relations, 2019, s.2.

5 Fuchs, Sosyal Medya: Eleştirel Bir Giriş, s.275.
} 
konuyu oluşturmaktadır. Bir başka deyişle, Twitter'da yer alan metalaşma, sömürü ve denetim ilişkilerinin çözümlenmesi çalışmanın sorunsalını oluşturmaktadır. Bu anlamda, çalışma Twitter'da yer alan metalaşma süreçlerinin bir parçasını değil tamamını bütünlüklü bir şekilde ele almayı amaçlamaktadır.

Çalışmada, Twitter kullanıcılarını kapsayan sömürü biçimlerinin ve metalaşma süreçlerinin ne olduğunu anlama çabasıyla hareket edilmiştir. Öte yandan, bu biçim ve süreçlerin açığa çıkarılması emek savunusu deneyimlerinde gerekli güncel bilincin, yol ve yöntemlerinin oluşması için toplumsal bir öneme de sahiptir. Kullanıcıların aynı zamanda, değer yaratan emek süreçlerinde emek ürününü ortaya çıkaran kimseler olduğu düşünüldüğünde bu önem daha anlaşılır kılınmaktadır. Sosyal medya kullanıcılarının sömürülmesi, emek piyasalarında yer almayan işçilerin sömürülmesiyle ve bunun da ötesinde insanların siber-zaman ve mekândaki etkinliklerinin bu sömürünün önemli bir parçası haline gelmesiyle eşanlamlıdır. Bu sömürülme biçimlerini daha ayrıntılı olarak anlamaya çalışan bu çalışmanın ulaşacağı sonuçlar, iletişim araştırmalarında emeğin bugününü anlama ve sömürünün güncel biçimlerini ortaya koymak için önemlidir.

Araştırmanın temel amacı ise günümüzde artı değer yaratımının geleneksel üretim mekânlarının dışına çıktığını ortaya koymak ve iletişim teknolojilerinin buna sağladığı olanakları sergilemek, dijital ortamlardaki kullanıcı emeği ve metalaştırılma süreçlerini göstermek ve yaratılan emeğin sermaye birikimine mal edilmesinde ilkel birikim yönteminin rolünü gözler önüne sermektir. Sözü edilen amaç doğrultusunda aşağıda yer verilen araştırma sorularına yanıtlar aranmıştır:

(1) Emeğin Twitter'da büründüğü nitelik nasıl açıklanabilir?

(2) Twitter'da metalaşma süreçleri nasıl işlemektedir?

(3) Twitter'da yer alan denetim süreçleri dijital emek, mülkiyet ve ilkel birikim üzerinden nasıl açıklanabilir?

Çalışmanın amaç ve sorunsalına ilişkin belirtilen noktalar bir arada düşünüldüğünde; Twitter'a yönelik eleştirel bir bakışın Twitter'da örtük bir biçimde süregelen eşitsiz ilişkilerin açığa çıkarılmasında yararlı olduğu düşünülmektedir. Bu düşünce, çalışmanın amaç ve sorunsalı için anlamlı olduğu kadar çalışmanın üzerinde yükseldiği kuramsal yaklaşım için de önemlidir.

\section{Çalışmanın Kuramsal Yaklaşımı}

Değişim ilişkisinin gelişme süreci ve para biçiminin ortaya çıkışı, metaların birbiri karşısında eşitlenmesine dayanmaktadır. Eşit metalar arasında bir metanının değerinin başka bir meta aracılığıyla ifade edilmesi, aynı zamanda başka metaların tek bir metayla ifade edilmesini de olanaklı kılmaktadır. Bu eşitleme işlemleri ve değer biçimindeki gelişmeler para biçimini ortaya çıkarmıştır. ${ }^{6}$

Basit meta dolaşımının temel mantığı meta sahibinin elindeki metayı satarak paraya

6 Karl Marx, Kapital, cilt 1, çev., Mehmet Selik ve Nail Satılgan, İstanbul: Yordam Kitap, 2016, s.61-81. 
çevirmesine, edindiği parayla başka bir meta edinmesine dayanmaktadır. Metaların başkalaşımı olarak ifade edilen bu durumu Karl Marx, "satın almak için satmak" olarak tanımlamaktadır. ${ }^{7}$ İlk metayı elden çıkaran sahibi, sürecin sonunda başka bir biçimde ve ilk metayla aynı değere sahip ikinci bir meta elde etmektedir. Değişim, metaların tüketilen kullanım değerlerinin niteliğinde yaşanmaktadır. ${ }^{8}$ Sürece sermaye olarak dahil olmayan para, değişimin aracı olarak dolaşıma katılmaktadır. ${ }^{9}$

İkinci dolaşım biçiminde ise metalar dolaşımın aracı haline gelmektedir. Bu dolaşımda, ilk olarak para sahibi olan kimseler bu parayla elde ettiği metalardan tekrar para elde etmektedir. Böylece, başlangıçtaki parayla, dolaşımın sonundaki para arasında nitel bir farklılık olmamaktadır. Bu dolaşım sürecine içeriğini kazandıran şey iki uç arasında gerçekleşen nicel farklılıktır. ${ }^{10}$

Sözü edilen dolaşım biçiminde, sürecin sonundaki para sürecin başındaki para ile birlikte bir fazlalığa eşit olmaktadır. Marx bu fazlalığa, artı değer adını vermektedir. Sürecin başında ve sonundaki para nicel olarak birbirinden farklı olmasına karşın nitel olarak aynıdır. Marx, sürecin sonundaki paranın para olarak harcanması durumunda rolünü bıraktı̆̆ını, sermaye olmaktan çıktığını vurgulamaktadır. ${ }^{11}$ Rolünü bırakmak, sermayenin paradan farkını anlamak adına önemli bir ifadedir. Sermaye, bir amaca özgülenmiş para olarak karşımıza çıkmaktadır. Para, bu süreçte özel bir rolü olduğu ölçüde sermayedir ki, bu özel rol değerin büyümesidir. Michael Heinrich, sermayeyi şu ifadelerle tanımlamaktadır: "Sermaye yalnızca değer değildir, o daha ziyade P-M-P’ hareketini gerçekleştiren değer toplamı anlamında kendini değerleyen değerdir." ${ }^{2}$

Kapitalist bir firma üretim sürecine para biçimindeki bir değerle başlamakta; firma tarafından bu para, yeni bir metanın üretimi için kullanılacak metaların satın alımı için kullanılmaktadır. ${ }^{13}$ Üretilen metaların satımından elde edilecek para ise o metaları üretirken kullanılan metaların satın alımında ödenen paradan daha yüksek miktarda olmalıdır. ${ }^{14}$ Kapitalist firmanın ilk parası ile son parası arasında farkın oluşması için kapitalist tarafından üretim araçları ve emek gücü satın alınmalıdır. Emek sürecinin sonunda kapitalist ilk başta aldığı bu iki meta sayesinde ve onlardan farklı metalar elde etmektedir. Üretim sürecinde, emek gücünün üretim araçlarını kullanarak ürettiği metalara kapitalist sınıf tarafından el konulmaktadır.

Üretim sürecinde, emeğin dışında kalan girdiler kendi değerinden fazlasını sürecin

7 Marx, Kapital, cilt I, s.152.

8 Duncan Karl Foley, Kapital'i Anlamak: Marx’ın İktisat Teorisi, çev., Hakan Öngel, Ankara: Arkadaş Yayınevi, 2010, s.41.

9 Petr Ivanovich Nikitin, Ekonomi Politik, çev., Hamdi Konur, Ankara: Sol Yayınları, 2002, s.70.

10 Marx, Kapital, cilt I, s.152 ve 155.

11 Marx, Kapital, cilt I, s.155-156.

12 Michael Heinrich, Kapital’e Giriş, çev., Koray R. Yılmaz, İstanbul: Yordam Kitap, 2017, s.96.

13 Foley, Kapital'i Anlamak: Marxin İktisat Teorisi, s.42.

14 Bu durumda, Para-Meta-Başkalaşmış Para (P-M-P') ifadesine daha açık bir şekilde bakmak gerekmektedir: P-M $\{\ddot{U} A, E G\} . .(\ddot{U})$...M'-P’. Burada, üretim araçları (ÜA) ve emek gücü (EG), kapitalistin ilk olarak satın aldığ metalardır. Aynı zamanda, bu metalar emek sürecinin (Ü) girdilerini oluşturmaktadır. Satılan metalar ise başlangıçta alınandan farklı, üretilen metalardır. Bkz. Foley, Kapital'i Anlamak: Marx’ın İktisat Teorisi, s.42. 
sonucundaki çıktıya aktaramamaktadır. Artı değer, ancak emek gücü değerinin harcadığı emek zamanda yarattığı değerden daha az olmasılla sağlanmaktadır. ${ }^{15}$ Artı değer yaratımında, kapitalist, emek gücü harcanan zamanın sadece bir kısmını emek gücü değeri olarak ödemektedir. Gerekli emek zaman ve artı emek zaman bu noktada önemlidir. Gerekli emek zamanda işçi emek gücü değerini yeniden üretmektedir ve bu zamanda aktarılan değer kapitalist tarafından ücret şeklinde emek sahibine ödenmektedir. Artı ürünün üretimi için harcanan emek zaman ise artı emek zaman olarak ifade edilmektedir. Artı emek zamanın gerekli emek zamana oranı işçinin sömürü oranına karşılık gelmektedir. ${ }^{16}$

Artı değer üreterek sermayenin değerlenmesini sağlayan işçi üretici işçi konumundadır. ${ }^{17}$ Marx’a göre emek, doğrudan doğruya artı değer sağlamak üzere işe alındıklarında üretici olmaktadır. ${ }^{18}$ Öte yandan, üretici olmayan işçiler de ücretlerinin karşılık geldiği değerden daha fazla çalıştığı durumlarda sömürülmekte ve üretici olmama durumu kapitalist sömürüyü engellememektedir. Marx için ücretlendirilmeyen emeğin üretken emek olmadığını ve ücretsiz emek tarafından artı değer yaratılmayacağına ilişkin görüş Marksist feministler tarafından eleştirilmiştir. ${ }^{19}$ Ücretsiz emeğin belirleyici özellikleri şöyledir: (1) Bedava olması, (2) Özgür olması, (3) Sermaye tarafından sömürülüyor olması. ${ }^{20}$

Self-servis uygulamalarında, tüketiciler mal ve hizmet tüketirken aynı zamanda ücretlendirilmeden çalıştırılmaktadır. Ayrıca tüketiciler, bu eylemlerle dolaşım ve dağıtım ilişkileri içerinde yer almaktadır. Tüketiciler ücretsiz olarak çalıştırılırken; işçi sınıfı içinde bulunanlarsa beden gücüne dayalı düşük ücretli işlerde yer alabilmektedir. ${ }^{21}$ Kapitalist tarafından self-servis uygulamalarında işin yapılması için herhangi bir işçi istihdam edilmezken, iş tüketiciler tarafından gerçekleştirilmektedir. Tüketicinin gördüğü bu iş, kapitalisti emek gücü satın almaktan "kurtarırken”; artı değeri arttırmaktadır. Dolayısıyla, tüketiciler tarafından görülen bu iş Marx’a göre üretken emek niteliği taşımaktadır, ancak ücretsiz bir emek olarak karşımıza çıkmaktadır.

Artı değerin ençoklaştırılması, parayı sermaye niteliğine büründürürken; artı değer üretiminin gerçekleştirilmediği ve sermaye krizlerine neden olan durumlar da yaşanmaktadır. Kapitalist üretim sürecinde sermaye zorunlu olarak (1) Para sermayenin üretici sermayeye dönüştürülmesi, (2) Üretici sermayenin, üretimin sonundaki sermayeyi üretimin başındaki sermayeden daha fazlalaştırması için meta üretimi ve (3) Metaların yeniden paraya çevrilmesi aşamalarından geçmektedir. Bu aşamalardan oluşan ve artı değerin ençoklaştırılması için sürekli devam eden bu döngünün sü-

15 Ben Fine ve Alfredo Saad-Filho, Marx’ın Kapital'i, çev., Nail Satlıgan, İstanbul: Yordam Kitap, 2012, s.52-53. 16 Nikitin, Ekonomi Politik, s.76-77.

17 Marx, Kapital, cilt I, s.486.

18 Fine ve Saad-Filho, Marx’in Kapital'i, s.61-62.

19 Andreas Wittel, “Sayısal Marx: Dağıtık Medyanın Ekonomi Politiğine Doğru”, Marx Geri Döndü: Medya, Meta ve Sermaye Birikimi, der., Vincent Mosco-Christian Fuchs, çev., Özgün Dinçer, Türkçe Yay. der., Funda Başaran, Ankara: NotaBene Yayınları, 2014, s.405.

20 Wittel, “Sayısal Marx: Dağıtık Medyanın Ekonomi Politiğine Doğru”, s.408.

21 Martha E. Gimenez, “Özkaynak Kullanımı: Şirketler Bizi Nasıl Ücret Ödemeden Çalıștırıyor?”, Çağdaş Marksizm Seçkisi, der., Bertell Ollman ve Kevin B. Anderson, çev., Şükrü Alpagut, İstanbul: Yordam Kitap, 2018, s.188-192. 
reklilik halinin kesildiği durumlarda artı değer üretimi olmamaktadır. ${ }^{22}$ Bunun yanı sıra, üretici kaynaklarını geliştiremeyen bir kapitalistin rekabet koşullarında batma riski bulunmaktadır. Bütün üreticilerin meta satışından en çok kârı elde etmenin ve üretilmesi gereken metaların cinsini ve miktarını tam olarak bilememesinin bir sonucu olarak üretimde anarşi meydana getirecek bir düzensizlik içinde üretim yapilmaktadir. ${ }^{23}$

Kapitalist üretim tarzında mal fazlalığı da sorun oluşturmakta, yaklaşık onar yıllık aralıklarla gelişmiş kapitalist toplumlarda krizler yaşanmaktadır. Hızlı birikim süreçlerini, durgunluk ve kriz izlemekte; ardından da birikimde önce yavaş sonra giderek hızlanan bir şekilde iyileşmeler meydana gelmektedir. Emek gücüne ödenen ücretler her zaman ürünün toplam değerinden daha düşük olmakta; ücretlerin yüksek olması gibi bir durumda bile ücretler toplam ürün için yeterli talebi asla karşllayamamaktadır. ${ }^{24}$ Kapitalizm için bunalıma sürüklenmekle sonuçlanan bu çelişki, aynı zamanda kapitalizmi yeni pazarlar arama ve bunalımdan kurtulma çabasına itmektedir. ${ }^{25}$

Amacı sürekli genişlemek ve sermayeyi yeniden üretmek olan bir ekonomik yapı, aşırı üretim durumunda ya da sermaye birikiminin gerçekleşmemesi durumunda bunalıma girmektedir. Bu krizlerden kurtulmaya çalışan yapı, belli zamanlarda yeni birikim düzenleri ortaya çıkarmaktadır. ${ }^{26}$ Kapitalist üretim tarzında krizler sisteme içkin bir şekilde var olmaktadır. Devamlı üretmek isteyen sermaye, krize girdiği anda yeni pazarlar aramaktadır. Bu anlamda, son otuz yıldır iletişim alanı sermaye için yeni bir birikim alanı haline gelmiştir.

Marx, sermaye birikimine bakarken, kapitalist üretimi önceleyen bir ilkel birikimin varlı̆̆ını kabul ederek analizini geliştirmiştir. Özellikle, çalışanların zenginleştiği ve tembellerin "kendi derilerinden başka satacak" hiçbir şeylerinin kalmamasına ilişkin anlatıya karşı Marx, ilkel birikim yöntemlerinin kesinlikle saf ve temiz olmadığını belirtmekte ve buna ilişkin olarak "Gerçek tarihte, en önemli rolün fethin, boyunduruk altına almanın, soygun için insan öldürmenin, kısaca zorun oynadığ bilinir" ${ }^{27}$ ifadelerini kullanmaktadır. Kapitalist üretim ilişkilerinde, üretim araçlarının özel mülkiyetine sahip kapitalist sınıf ve geçim araçlarını edinebilmek için emek gücü metasından başka mülkiyeti olmayan işçi sınıfı bulunmaktadır. Bu iki sınıf arasındaki bölünme ilkel birikimle gerçekleşmektedir. ${ }^{28}$ İlkel birikim üreticinin üretim araçlarından koparılmasını, toplumsal geçim araçlarını sermayeye, doğrudan üreticileri

22 John Eaton, Ekonomi Politik-Marksist Bir El Kitabı, çev., Şiar Yalçın, Ankara: Bilim ve Sosyalizm Yayınları, 1978, s.235.

23 Nikitin, Ekonomi Politik, s.62.

24 Heinrich, Kapitale Giriş, s.191-192.

25 Eaton, Ekonomi Politik-Marksist Bir El Kitabı, s.239.

26 Haluk Geray, “Birikim Düzenleri, Yeniden Yapılanma ve Küreselleşme”, İletişim Ağlarının Ekonomisi, der., Funda Başaran ve Haluk Geray, Ankara: Ütopya Yayınevi, 2016, s.42.

27 Marx, Kapital, cilt I, s.687.

28 Jernej Prodnik, "Sürüp Giden Metalaşma Süreçleri Üzerine Bir Not: İzleyici Metasından Toplumsal Fabrikaya”, Marx Geri Döndü: Medya, Meta ve Sermaye Birikimi, der., Vincent Mosco-Christian Fuchs, çev., Zafer Kıyan, Türkçe Yay. der., Funda Başaran, Ankara: NotaBene Yayınevi, 2014, s.312. 
ise ücretli emekçilere dönüştüren tarihsel bir süreç olarak karşımıza çıkmaktadır. ${ }^{29}$

İlkel birikim süreçlerinin kapitalizmin tarih öncesinde sınıflar arası bir kopuşa neden olacak bir şekilde yaşanıp bittiğine ilişkin görüşün yanı sıra, ilkel birikimin süreklilik arz eden bir yöntem olduğunu belirten yaklaşımlar da bulunmaktadır. Marx’ın kuramında "süreklilik" durumunun varlığına ilişkin vurgu noktaları bulunmakta ve Marx’tan yapılan şu kısa alıntılar bu düşünceyi beslemektedir. "I0 "İşçinin bu biçimde sürekli üretilmesi ya da ebedileştirilmesi, kapitalist üretimin vazgeçilmez koşuludur"; "(Kapitalist üretim süreci)... işçiyi, sürekli olarak, yaşayabilmek için bu emek gücünü satmaya zorlar ve kapitalisti, sürekli olarak zenginleşmek için bu emek gücünü satın alabilecek duruma getirir." ${ }^{31}$ Sistem olarak kapitalizm, işçinin üretim araçlarının mülkiyetinden dışlanmasını gerektirerek, bu mülksüzleştirme işlemini sürekli hale getirmektedir.

İlkel birikimin sürekliliğini savunan düşünürler arasında Rosa Luxemburg ismi öne çıkmaktadır. ${ }^{32}$ Luxemburg, genişleyen maddi üretimin kapalı bir kapitalist ekonomi tarafından sürdürülmeyeceğinin altını çizerken, kapitalizm dışından kaynaklanan talep türlerinin geçici bir çözüm sunacağını belirtmektedir. Bu nedenle, kapitalizmin içinde sermaye için "fethedilecek” pazarların oluşmasının gerekli olduğuna vurgu yapmaktadır. 33 “...kapitalizm tüm olgunluğunda bile, her yönden, yan yana birlikte var olduğu kapitalist olmayan katmanlara ve toplumsal örgütlenmelere dayanmaktadir." 34

Marx’ın yeniden üretim şemasına getirdiği eleştirileri temellendirmek için Luxemburg, birikimin tarihsel koşullarına odaklanmış ve sermayenin (1) Doğal ekonomiyle mücadele, (2) Meta ekonomisiyle mücadele, (3) Rekabet mücadelesi olmak üzere üç aşamada mücadele ettiğini belirtmiştir. Luxemburg, kapitalizmin kapitalist olmayan üretim biçimlerini "doğal ekonomiyle mücadele" kapsamında ele almış ve sermayenin buradaki amaçlarını şöyle sıralamıştır: (1) Üretim güçleri kaynaklarına sahip çıkmak, (2) Emek gücünü özgürleştirip kendi hizmetine sokmak, (3) Meta ekonomisi getirmek, (4) Ticaret ve tarımı ayırmak. ${ }^{35}$ "Sermayenin birikim süreci değişmeyen sermaye, değişen sermaye ve artı değerle, kapitalist olmayan üretim biçimlerine bağlıdır" açıklamasında bulunan Luxemburg’a göre, kapitalist olmayan bir ortamın yokluğu halinde sermaye birikimi her bakımdan olanaksızlaşmaktadır. ${ }^{36}$ Özetle, sermaye birikiminin içerisine kapitalist olmayan üretim tarzlarının dahil edilmesi gerekliliği, ilkel birikimin sadece kapitalizmin tarih öncesinde yaşanmadığını; aksine sermaye birikiminin devam eden bir parçası olarak görüldügünü ortaya koymaktadır.

Bununla birlikte, günümüz medyasının içine doğduğu ve yarattığı olanaklar tek bir

29 Özay Göztepe, İlkel Birikim ve Acele Kamulaştırma, İstanbul: NotaBene Yayınları, 2018, s.59.

30 Göztepe, Illkel Birikim ve Acele Kamulaştırma, s.60.

31 Marx, Kapital, cilt I, s.552 ve 558.

32 David Harvey, Marx’in Kapitali İçin Klavuz, çev., Bülent O. Doğan, İstanbul: Metis Yayınları, 2015, s.322.

33 Korkut Boratav, Emperyalizm, Sosyalizm ve Türkiye, İstanbul: Yordam Kitap, 2017, s.159.

34 Rosa Luxemburg, Sermaye Birikimi, çev., Tayfun Ertan, İstanbul: Alan Yayıncılık, 1986, s.278.

35 Göztepe, İlkel Birikim ve Acele Kamulaştırma, s.63-64.

36 Rosa Luxemburg, Sermaye Birikiminin Tarihsel Koşulları, çev., Neyyir Kalaycıŏlu, İstanbul: Kaynak Yayınları, 1984, s.45. 
sınıfın kullanımında değildir. Kaldı ki, medya ilkel birikim sürecinin etkisindeyse, sermaye birikiminin içerisine dahil edilerek değerlendirilmesi gerekmektedir. Bu anlamda, hem geleneksel hem de yeni medya ortamları ilkel birikimin somutlandığı mecralar olarak karşımıza çıkmaktadır. Dolayısıyla, günümüz medya yapısıyla sermaye birikimi arasındaki ilişkiyi anlamak için eleştirel ekonomi politik yaklaşımın iletişim alanındaki bazı açılımlarını irdelemek yerinde olacaktır.

Smythe, yaklaşı 40 yıl önce izleyici metası kavramsallaştırmasını geliştirmiş ve günümüze kadar uzanan tartışmaların temelini atmıştır. Smythe, o güne kadarki iletişim çalışmalarında, kitle iletişim araçlarıyla üretilen ve reklamcıların satın aldığı, kullandığı izleyici piyasasının ihmal edildiğini vurgulamıştır. ${ }^{37}$ Smythe, kitle iletişim sistemlerinin "kapitalist üretim ilişkilerinin yeniden üretimdeki rollerini açığa çıkarmak" amacıyla "reklam destekli iletişimin kitlesel olarak üretilen meta biçimi nedir?" sorusuna yanıt aramış ve bu sistemlerin sermaye için yerine getirdiği işlevleri irdelemiştir. $^{38}$

Kitle iletişim sistemlerinde, reklamcılar izleyicilerin dikkatini satın alan reklam harcamalarında bulunmaktadır ve kitle medyasının içeriği izleyicilerin dikkatlerini sürdürme işlevi gören "bedava öğlen yemekleri”dir. İzleyicilerin programa bağlllıklarının korunması ve reklamcıların mesajlarına uygun reaksiyon verecek izleyiciler yaratılması ise bu durumun bir sonucudur. ${ }^{39}$ Ayrıca, izleyici metası tartışmasında, izleyicilerin satılan zamanının izleyiciler tarafından değil, kitle iletişim medyası tarafından reklamverenlere satılmas $1^{40}$ bir diğer önemli noktadır.

Kapitalist üretim ilişkilerinde yaşanan dönüşümlerle işçilerin "serbestleştirilmiş" zamanının iddia edildiği gibi serbestleştirilmediğini savunan Smythe, uyku dışında kalan tüm zamanın iş zamanı olduğunu ifade etmektedir. İzleyici, üretken emek niteliği sergilemektedir. Uyku dışı kalan boş zamanlarda reklamcılara satılan izleyiciler üretilen ve piyasada satılan bir meta haline gelirken ${ }^{41}$; bu durum, izleyicinin reklamcılar için pazar işlevini yerine getirmesi ve emek gücünün yeniden üretiminin gerçekleştirilmesi gibi sonuçları olmaktadır.

Sut Jhally ve Bill Livant izleyici metası tartışmasını sürdürmüş ve Marx’ın iktisadi kavram setlerini medya ekonomisine uyarlamıştır. Metalaşan şeyin zaman olabileceğine ilişkin önceden oluşturulan Livant'ın ham düşünceleri ikili tarafından geliştirilmiştir. Onlara göre, izleme aynı zamanda çalışma anlamı taşımaktadır ve izleme sırasında emek harcayan işçi izleme gücüne sahip kimsedir. Gerekli emek zamanı dışında kalan fazladan izleme zamanı ise artı izleme zamanıdır. ${ }^{42}$

37 Haluk Geray, “Geleneksel Medyada Reklamcılık”, İletişim Ağlarının Ekonomisi, der., Funda Başaran ve Haluk Geray, Ankara: Ütopya Yayınevi, 2016, s.156.

38 Zafer Kıyan, Metalaştırma ve Direnç: Kapitalizmde Kültürün İkili Üretim Yapısı, Ankara: NotaBene Yayınları, 2016, s.184.

39 Smythe, "Batı Marksizminin Kör Noktası", s.133 ve 135.

40 Erdal Dağtaş ve Mehmet Emir Yıldız, “Türkiye’de 'İzleyicinin Metalaşması’: Televizyon Dizilerinin Sosyal Reyting Ölçümlerinin Eleştirel Ekonomi Politik Çözümlemesi”, Global Media Journal TR Edition, 5/10 (2015), s.127.

41 Prodnik, "Sürüp Giden Metalaşma Süreçleri Üzerine Bir Not”, s.337.

42 Sut Jhally ve Bill Livant, "Watching as Working: The Valorization of Audience Consciousness", The Spectacle of 
İletişim alanında medyanın eleştirel ekonomi politiği, kitle medyası çağında inşa edilen bir akademik alandır. Dolayısıyla, kitle medyası çağının belirleyici özelliklerinden biri olan medya içeriğinin az sayıdaki üreticiden çok sayıdaki alıcıya doğru çizgisel ve tek yönlü izlediği $\mathrm{ak}_{1} \varsigma^{43}$, medyanın eleştirel ekonomi politiğinin iskeletini belirlemede önemli rol oynamıştır. Kitle iletişim çağında medyanın eleştirel ekonomi politiği Marksist kavramlarla sınırlı bir şekilde ilgilenmekte ve bu sınırlı ilişki kitle medyası teknolojilerinin temel mantığına bakıldığında anlaşılabilir bir hal almaktadır. ${ }^{44}$ Sözü edilen sınırlı ilişkinin nedeni, neo-liberal politikaların iletişim süreçlerine olan etkileri ve iletişim araçlarında yaşanan yapısal dönüşümler kadar medyanın sermaye birikiminin belirgin bir nesnesi olarak tanımlanmamasıdır. Kaldı ki, küreselleşme sürecinin sosyo-ekonomik ve siyasal etkilerinin medya alanındaki gelişmelerle bütünleşmesiyle birlikte, basın döneminden medya dönemine geçilmiştir. Önceleri kitle iletişim araçlarının temel işlevi topluma haber ve bilgi aktarımı iken; günümüzde medyanın temel işlevlerinde de önemli farklılıklar yaşanmıştır. ${ }^{45}$

Öte yandan, iletişim alanında yaşanan sayısallaşma olgusu, yöndeşme ve tekelleşme eğilimlerinden bağımsız düşünülemez. Devlet eliyle uygulanan özelleştirme ve deregülasyon politikalarının bu eğilimleri olanaklı kıldığı söylenmelidir. Bu değişimle birlikte, iletişim alanı bir bütün olarak ticarileşerek sermayenin pazarı haline gelmiştir. İletişim alanında yaşanan dönüşümlerle "kamusal yarar" ilkesi rekabet gücü sağlama, verimlilik, ekonomik kazanım vb. hedeflerin arkasında kalmıştır. ${ }^{46}$

Günümüz medya atmosferini dağıtık medya çağı olarak nitelendiren Andreas Wittel’e göre, dağıtık medya ve sayısal medya benzer olmalarına karşın farklı anlamlara gelmektedir. Sayısal medya sadece teknolojiye karşılık gelmekte, dağıtık medya ise medyanın toplumsal örgütlenmesini de kapsamaktadır. Dağıtık medyayı şekillendiren sayısal teknolojilerin nitelikleri ve kapasiteleridir. Bu kapasiteler (1) Eski medya biçimlerini sayısal kodlar olarak yeniden yayabilme, (2) İletişim ve enformasyonu ya da iletişim araçlarını kitlesel medyayla bütünleştirebilme, (3) Sayısal nesnelerin az maliyetle yeniden üretilebilmesi, (4) Ağırlık arz etmemeleri ve sşık hızında yayılmaları olarak sıralanabilir. Ayrıca, dağıtık medyaya özgü durumlar vardır. İlki, dağıtık medya çağında üretim araçlarının sahipliği medya içeriği kadar erişim konusuyla da ilgidir. İkincisi ise üretim araçlarına sahipliğin görece daha demokratik bir hale gelmesine karşın dağıtım ve depolama araçlarına sadece birkaç holdingin sahip olmasidir. $^{47}$

Sermaye birikimi, iletişim alanında yaşanan dönüşümler ve izleyici metası tartışmalarının bugüne olan yansımaları bir arada düşünüldügünde; medyanın ekonomi po-

Acculamation: Essays in Culture, Media \& Politics, der., Sut Jhally, New York: Peter Lang Publishing, s.25-43'ten aktaran Kıyan, Metalaştırma ve Direnç, s.201-202.

43 Wittel, “Sayısal Marx: Dağıtık Medyanın Ekonomi Politiğine Doğru”, s.391.

44 Wittel, “Sayısal Marx: Dağıtık Medyanın Ekonomi Politiğine Doğru”, s.390-394 ve 397-398.

45 Ahmet Raşit Kaya, “Türkiye Siyasal Yaşamında 1980’ler Sonrası Gelişmeler ve Medya”, Türkiye’de Kitle İletişimi: Dün, Bugün, Yarın, der., Korkmaz Alemdar, Ankara: Gazeteciler Cemiyeti Yayınları, 2009, s.233.

46 Aylin Aydoğan, "Enformasyon ve İletişim Hizmetleri: Kamusal Faydayı Yeniden Düşünmek", İletişim Ağlarında Yeni Hizmetler, der., Funda Başaran ve Haluk Geray, Ankara: Ütopya Yayınları, 2016, s.8.

47 Wittel, “Sayısal Marx: Dağıtık Medyanın Ekonomi Politiğine Doğru”, s.398-399. 
litiğinin Marksist kavramlar ile olan sınırlı ilişkisinin kitle iletişim çağındaki kadar fazla olmadığını söylemek mümkündür.

Christian Fuchs, sosyal medyayla birlikte izleyici metasının yaygınlaştığını belirterek; "tüm gezegen kapitalist bir fabrikadır" benzetmesinde bulunmaktadır. İnternet kullanıcıları da her şeyin metalaşmasının bir parçası haline gelmektedir. ${ }^{48}$ Fuchs sosyal ağlar, meta üretimi ve reklamcılığı esas alan modelinde, daha önce sözü edilen sermaye sürecine ${ }^{49}$ ilişkin bazı güncellemelerde bulunarak sosyal medyada sermaye sürecini daha anlaşılır kılmayı hedeflemiştir. ${ }^{50}$

Sosyal medya şirketleri, herhangi kapitalist bir şirket gibi kârını ençoklaştırmak amacını taşımakta ve bu amaçla üretim araçları ve emek gücü satın almaktadır. Bu şirketler tarafından alınan altyapı ve teknolojiler üretim araçları olarak tanımlanırken; çalışanlar ise ücretli emek kapsamında değerlendirilmektedir. Fuchs'un modele olan katkısı ise bundan sonra belirginleşmektedir. Sosyal medya platformundaki içerikleri üreten ücretsiz emeğin de birikim sürecine dahil edilmesiyle bu platformlar ve ücretsiz emek, üretim sürecinin sonucunda ortaya çıkan metanın farklılaşmasında önem kazanmaktadır. ${ }^{51}$ Fuchs, sosyal medya platformunu doğrudan satılan bir meta olarak değil; ücretsiz emek tarafından içerik üretimine olanak sağlayan, dolayısıyla üretüketici metasını ortaya çıkaran bir yapı olarak görmektedir. ${ }^{52}$ Öte yandan, çoğunun meta olmadığ ve ücretsiz olarak kullanıma sunulan sosyal medya hizmetlerine karşın, kullanıcıların verilerinin ve kullanıcıların sosyal medya metası olduğuna ilişkin Fuchs'un yaptığı saptama önemlidir. ${ }^{53}$ Üretüketici durumuna geçen internet kullanıcılarının ürettikleri artı değer sermaye tarafından sömürülmekte ve kullanıcılar "üretken kimseler" haline dönüşmektedir. Sermaye birikim sürecine katkı sağlayan sosyal medya içeriği üreten kullanıcılar sermaye tarafından ücretlendirilmemekte; elde edilen artı değer artarken sermaye tarafından emek gücüne yapılan ödemeler aynı kalmaktadır. Bu sayede kâr oranını arttıran sosyal medya şirketinin içerik üreticilerinin kullanıcı emeğini ücretlendirmesi söz konusu olduğunda, sermayenin maliyet girdisi artmakta ve kâr oranı düşmektedir. ${ }^{54}$ Sosyal medyada emeğin ücretlendirilmemesi dikkate alındığında, artı emek zamanı kullanıcıların emek gücünü harcadığ 1 zamanın tamamına denk gelmektedir. Bununla birlikte, üretüketicilerin sosyal medyadaki faaliyetlerinin hepsi metalaşmamakta, ticari olmayan kuruluşlarca yapılan içerik üretimi metalaşmanın dışında kalmaktadır. ${ }^{55}$

Sermaye birikim modelinin içinde bulunan üretüketici metası ve sosyal medya şirketlerinin bu üretüketici metası aracılığıyla kâr ve sömürü oranını arttırması Twit-

48 Fuchs, Sosyal Medya: Eleştirel Bir Giriş, s.163.

$49 \mathrm{Bu}$ sürecin formülasyonunun şu şekilde olduğu ifade edilmişti: P-M\{ÜA, EG\}...(Ü)... M’-P'

50 Christian Fuchs, Dijital Emek ve Karl Marx, çev., Tahir Emre Kalaycı ve Senem Oğuz, İstanbul: NotaBene Yayınlar1, 2015, s.155-169.

51 Fuchs, Dijital Emek ve Karl Marx, s.155-169.

52 Kıyan, Metalaştırma ve Direnç, s.205. Ayrıntılı bilgi için bkz. Fuchs, Sosyal Medya: Eleştirel Bir Giriş ve Dijital Emek ve Karl Marx; Kıyan, Metalaştırma ve Direnç.

53 Fuchs'un katkılarıyla formül şu hali almıştır: P-M\{ÜA, EG, Ü1\}...(Ü) $\left\{\ddot{U}_{1}, \ddot{U}_{2}\right)$...M'-P'. Burada, (Ü) emek sürecini, $\left(\ddot{U}_{1}\right)$ sosyal medya platformunu, $\left(\ddot{U}_{2}\right)$ ücretsiz emeği ve $M^{\prime}$ üretüketici metasını ifade etmektedir.

54 Fuchs, Sosyal Medya: Eleştirel Bir Giriş, s.151-153.

55 Fuchs, Dijital Emek ve Karl Marx, s.181. 
ter'da da yaşanmaktadır. Twitter'da kullanıcıların hem medya içeriği üretmeleri hem de etkileşimde bulunmaları, kullanıcıların tüketici özelliklerine ek olarak üretici özelliklerini de belirginleștirmektedir. ${ }^{56}$ Web 2.0 temelinde çevrimiçi araçların yard1mıyla "gündelik yaşamın olağan bir haline gelmekle" nitelendirilen sosyal paylaşım siteleri, yeni iletişim araçlarının üretim araçlarına dönüşmesine örnek gösterilmektedir.

\section{Çalışmanın Yöntemi}

Nitel çözümleme yönteminin benimsendiği bu çalışma kapsamında, 10 kişiden oluşan bir örnek araştırma grubu belirlenmiş ve bu kişilerle yarı yapılandırılmış derinlemesine görüşmeler gerçekleştirilmiştir. Katılımcılar belirlenirken, metin temelli çözümleme üzerinden saptanan amaçlı örnek araştırma grubu oluşturulmuştur.

Bu bağlamda, Twitter'da 20 Temmuz-18 Ağustos 2019 tarihleri arasında Kazdağları'yla ilgili tweet atan kullanıcılar araştırmaya dahil edilmiştir. Tema olarak Kazdağları’nın seçimi iki noktada önemlidir. Birinci nokta çalışmada yer alacak görüşmecilerin mülksüzleştirme rejimlerine ilişkin geliştirebileceği düşünce ve yaklaşımların olabileceği varsayımıdır. İkinci nokta ise Kazdağları üzerinde bir sermaye grubuna altın arama ruhsatı verilmesinin önemli bir toplumsal soruna karşılık gelmesinin öngörülmesidir.

Bu kapsamda, araştırma için örnek araştırma grubu oluşturulurken üç önemli değişken etkili olmuştur. Bunlar, (1) Hesabın kilitli olmaması ve doğrudan mesaj özelliğinin açık olması, (2) Hesabın konum bilgisini bulundurması, (3) Twitter'a katılım tarihidir. Bu kriterler gözetilerek, ilgili hesaplara metin temelli analiz uygulanmıştır. Kullanıcı profilinin ve doğrudan mesaj özelliğinin herkese açık olması, kişilere ulaşmak için önemli bir koşuldur. Örnek araştırma grubunu oluşturacak kişilerle Twitter üzerinden iletişim kurulması amaçlanmıştır. Hesabın konum bilgisi ise araştırmanın sınırlıklarıyla ilgili olmakla birlikte, Ankara konum bilgisi bulunanlar dışındaki diğer kullanıcılara yönelik görüşme talebinde bulunulmamıştır. Twitter’a katılım tarihi ise kullanıcıların Twitter’a ilişkin deneyim düzeyiyle ilişkili olarak belirlenmiştir. Görüşülen kişilerin, en az üç yıllık bir Twitter kullanıcısı olmasına önem gösterilmiştir.

13 Mart-17 Nisan 2020 tarihleri arasında yapılan görüşmeler eşit sayıda iki kategoride gerçekleştirilmiştir. Bunlar, görüşmecilerin dijital yerli ve dijital göçmen olma durumlarıdır. Bu nedenle, yaş da önemli bir değişkeni oluşturmaktadır. Bu görüşmelerde, 1985 yılından önce doğan 5 dijital göçmen ve sonra doğan 5 dijital yerliden oluşan toplam 10 Twitter kullanıcısı üzerinden çalışmanın sorunsalı ve amacına ilişkin veriler elde edilmiştir. ${ }^{57} \mathrm{Bu}$ kapsamda, araştırmanın dört katılımcısıyla aynı fiziki ortamda yüz yüze, iki katılımcıyla WhatsApp uygulamasının görüntülü konuşma özelliği kullanılarak ve dört katılımcıyla da Skype uygulamasının görüntülü toplantı

56 Kıyan, Metalaştırma ve Direnç, s.204.

57 Katılımcılar çözümleme bölümünde, dijital yerli ve dijital göçmen oluşlarına göre belirlenmiş kısaltmalar ile ifade edilmiştir. Bu kısaltmalar, dijital göçmenler için DG-1, DG-2, DG-3, DG-4, DG-5; dijital yerliler için ise DY-1, DY-2, DY-3, DY-4, DY-5 olarak belirlenmiştir. 
özelliği kullanılarak görüşmeler gerçekleştirilmiştir. ${ }^{58}$

10 Twitter kullanıcısı üzerinden çalışmanın sorunsalı ve amacına ilişkin veriler elde edilmiştir. Bu verilere ulaşmak üzere görüşmecilere araştırmanın sorunsalıyla, araştırma sorularıyla ve araştırmada önemli görülen konu başlıklarıyla ilişkili sorular yöneltilmiştir. Bu sorularda, Twitter'da emeğin ne şekilde algılandığı, Twitter'da yer alan metalaşma ve denetim süreçlerinin neler olduğuna ilişkin katılımcıların algıları, dijital yerli ve dijital göçmenler arasındaki fark ve benzerlikler ölçülmeye çalışılmıştır. Bu kapsamda, katılımcılara tek bir kişi tarafından yarı yapılandırılmış görüşme soruları yöneltilmiştir.

\section{Bulgular ve Yorumları}

Araştırma kapsamında yapılan yarı yapılandırılmış derinlemesine görüşmeden elde edilen bulguların yorumu şu üç altbaşlık altında gerçekleştirilmiştir: (1) Emeğin Twitter'da büründügü nitelik, (2) Twitter'da saptanan metalaşma süreçleri, (3) Twitter'da yer alan denetim süreçleri.

\section{Emeğin Twitter'da Büründüğü Nitelik}

Twitter üzerinde yer alan emek süreçlerini ve emeğin büründüğü niteliği saptamak, Twitter'daki metalaşma ve sömürü süreçlerini de açığa çıkartması bakımından öneme sahiptir. Dolayısıyla, katılımcıların çevrimiçi etkinliklerini bir üretim olarak değerlendirip değerlendirmemeleri burada önem kazanmaktadır.

Katılımcıların bu konuda kullandıkları bazı kesin ifadeler dikkat çekmektedir. Örneğin, DY-3 tarafından Twitter kullanıcılarının çevrimiçi etkinliklerinin bir üretim olarak değerlendirilmediği gözlemlenirken; DY-1 kullanıcı etkinliklerini "emek süreci" olarak nitelendirmektedir. DG-5 ise, Twitter kullanıcılarının çevrimiçi etkinlikleri arasında yaptığı ayrım ile özgün fikirler belirtmektedir:

İnsanlar sadece beğendiğini paylaşmak için vakit harcıyor. Ancak, harcadığın zamanın karşısında bir şey kazanılması gerekir. Sadece para değil, üretim olması da gerekir. Buralarda yapılan, gördüğünüz ve doğru olduğuna inandığınızı daha fazla insanın görmesi için yaptığımız bir eylem. Bunun karşılığında bir üretim söz konusu değil. İlk yazan kişinin bir üretimi var mıdır? Bunun için bir emek harcamış mıdır? Belki orada emek harcandığı sayılabilir ama bunu bir üretim olarak görmüyorum. Retweet edenlerin ya da beğenenlerin kesinlikle bir emeğinin olduğunu düşünmüyorum. İlk paylaşan kişiyse tartış1lir. ${ }^{59}$

DG-5, çevrimiçi etkinlikleri iki kategoride değerlendirmektedir. Birincisi tweet at-

58 Görüşmelerin, aynı fiziki ortamda yüz yüze yapılması düşünülmüştür. İlk görüşmeler bu düşüncenin bir sonucu olarak bu yöntemle gerçekleştirilmiştir. Ancak, araştırmanın yapıldığ 1 sırada dünyada ve Türkiye’de etkin bir şekilde kendini gösteren Covid-19 salgını nedeniyle, yapılan derinlemesine görüşmelerin tasarlanan bu yöntemle gerçekleştirilmesi mümkün olmamıştır. Dolayısıyla, elektronik toplantı ve görüntülü konuşma imkânı sağlayan uygulamalar aracılığıly bu görüşmeler gerçekleştirilmiştir.

59 DG-5 ile yapılan derinlemesine görüşme, 23.03.2020. 
mak, ikincisi farklı kullanıcılar tarafından dolaşıma sokulan içerikleri retweetlemek ve/veya beğenmektir. DG-5, ikinci durumun emekle ilişkisinin olmadığını ancak, birinci durumda emekle kurulan ilişkinin tartışılabilir olduğunun altını çizmektedir. Bu ikili ayrımda, katılımcının üretim ile kurduğu ilişki belirleyicidir. Tweeti ilk kez atan kullanıcıların üretim içinde bulunduğuna ilişkin zayıf da olsa düşünceler barındıran DG-5, ikinci durum içinde yer alan etkinliklerin herhangi bir üretim biçimi olmadığının altını çizmektedir. DY-3 de bu tarz mekânlarda üretime dayanmayan ilişkilerin olduğundan söz etmektedir.

Bu düşüncelere karşın, DY-1, Twitter kullanıcılarının çevrimiçi etkinliklerini “emek süreci” olarak tanımlamaktadır. Katılımcıyla yapılan görüşmede kullanılan "Kendi tweetlerinizi atarken bile 'ben ne yazarsam daha etkili olabilir', 'kendimi daha iyi nasıl anlatabilirim' diye düşünüyoruz. O da bir emek süreci, aktarma süreci”"60 ifadeleri önemlidir. Benzer olarak, Twitter'da ürettiği içerikleri emek ürünü olarak değerlendiren DY-5 "bazen yaptığım çalışmalara yönelik talep de oluşuyor. Ben de bu işi ilerletmeye çalışıyorum. İlerlemenin karşılığını da almak istiyorum. Yaptıklarımın bir emek ürünü olduğunu düşünüyorum" ${ }^{61}$ demektedir.

Görüşülen kişilerin, Twitter'da emek süreçlerinin var oluşunu iki şekilde ele aldığ 1 gözlemlenmektedir. Birincisi, emek süreçlerini Twitter'da gerçekleşen bir ilişki biçimi olarak ele alma; ikincisi ise Twitter içeriklerinin konusunu emek süreçlerinin oluşturup oluşturmadıklarına yönelik değerlendirme eğilimidir. Çalışmanın sınırlığı nedeniyle ve konuyla ilgisi bakımından ilk oluşan eğilimin üzerine gidilmiştir. Yukarıda örneklendiği gibi kesin ifadeler kullanmasa da elde edilen bulguların çözümlenmesiyle birlikte katılımcıların, Twitter'da yer alan emek süreçlerine ilişkin düşünceleri belirginlik kazanmaktadır.

Kimsenin olmadığı yerde bir olay çıkıyor ve olayın görüntüsünü ben alıyorum ve hesabımdan paylaşıyorum. Türkiye’de bilinen bir medya kuruluşuysa bunu bir imza belirtmeden -çünkü sosyal medyada paylaşıldığı zaman alınabilir gibi düşünüyor- paylaşabiliyor kurumsal hesabında. O görüntüye, o hesapta binlerce retweet ve beğeni yapılıyor. Bende ise bir şey olmuyor. Bunun, o medya kuruluşuna maddi bir getirisi olurken; bana herhangi bir getirisi olmuyor. Aslında, bu da bir sömürü şekli. Bir çalma... Hırsızlığa giriyor. Ben bunu bir kere yaşadim. ${ }^{62}$

DY-1'in verdiği örnek üzerinden gidilirse, katılımcı aynı işi geleneksel medya şirketlerinin çalışanı olarak yapsaydı yapılan işin üretim olup olmadığı, ortaya çıkan ürünün meta değeri taşıyıp taşımadığı tartışma konusu bile olmayabilirdi. Öte yandan, geleneksel medya şirketi, kullanıcı tarafından üretilen içeriği, kendi bünyesinde çalışan ücretli emek gücü tarafından üretilen içerikle benzer bir şekilde piyasa ilişkisine sunmaktadır. Tekil kullanıcının yaptığı, en az geleneksel medya içerisinde bulu

60 DY-1 ile yapılan derinlemesine görüşme, 17.03.2020. 61 DY-5 ile yapılan derinlemesine görüşme, 17.04.2020. 62 DY-1 ile yapılan derinlemesine görüşme, 17.03.2020. 
nan bir basın emekçisinin yaptığı kadar üretim olarak değerlendirilmelidir. Benzer olarak DG-1 de, tekil kullanıcıların ürettiği içeriklerin medya şirketleri vb. yerlerde kullanılabileceğinin altını çizmiştir.

DY-1 ve DG-1'in ifadelerinden, şirket olarak Twitter'ın değil, üçüncü tarafların kâr ettiği açığa çıkmaktadır. Twitter, bir platform olarak geçiş düzlemi görevi görmektedir. Bu haliyle, sosyal medyadaki etkileşimli yapının kapitalist şirketlerin kârını ençoklaştırmasının aracına dönüştüğü gözlemlenmektedir. Bunlara ek olarak, DY-5, benzer bir deneyimini şöyle aktarmıştır:

Ben fotoğraflar yapıyorum, ama takipçilerimde fazla bir artış yok. Büyük bir sayfa benim fotoğrafımı çaldı. O benden daha çok pirim kazandı. [...] Benim yaptığım bir şeyi sömürdüler gibi bir durum ortaya çıktı. Ve ben onlara yazdım, 'ismimi paylaşabilir misiniz?' diye ve daha sonra beni engellediler. ${ }^{63}$

Aktarılan örnekte, kendi emek ürünü sosyal medya platformu aracılığıyla başka kullanıcılar tarafından kendi yararları için kullanılmıştır. Burada karşılaşılan üçüncü kişiler, bir kurum ya da bir şirket değil; başka bir tekil kullanıcıdır.

Emek kavramının emek gücünün harcanmış hali olduğunu hatırlamak önemlidir. İnsanların emek gücünü sermaye sahibine satması, sermayenin özel mülkiyetinde bulunan üretim araçlarıyla bir araya gelmesi ve sonuçta, emek gücünü harcayarak emek ürünü yaratması bir gerçekliktir. Kuşkusuz anlatılan bu durum, emek ürünü yaratmanın tek koşulu değildir. Burada da görüleceği üzere, herhangi bir emek gücünü bir sermaye sahibine satmadan da emek ürünü meydana getirilmektedir. Kaldı ki, bu noktada emek gücünün bir sermaye sahibine satılmıyor olması ulaşılan bir özgürlük anlamına gelmemektedir. Kullanıcılar tarafından üretilen emek ürününün bir meta olup olmadığının anlaşılabilmesi için emek ürününün bir insan ihtiyacını karşılayıp karşılamadığına ve bir değişim ilişkisine girip girmediğine bakılmalıdır. Öncelikle, insan ihtiyacı genel bir kavramdır. Kaldı ki, ihtiyaçların genelliğine, "şu ya bu türden insan ihtiyaçlarını gideren dışsal nesne", "mideden mi hayalden mi kaynaklandığı hiçbir değişikliğe yol açmaz" "4 şeklindeki ifadelerle Kapital'de vurgu yapılmaktadır. Kullanıcı içeriklerinin hangi tür insan ihtiyacını karşıladığı düşünüldügünde; Feuerbach’a yönelik yazılan altıncı tez hatırlanmalıdır. Burada, yalıtılmış insan betimlemesine eleştiri yöneltilmektedir. ${ }^{65}$ Bireylerin kendi yeteneklerini geliştirmesinin biricik koşulu topluluğun var olmasıdır. ${ }^{66}$ Günümüzün sanal toplulukları olarak değerlendirilen Twitter vb. alanlar ise bireylerin yeteneklerini geliştirme ihtiyacının toplum içinde var olma ihtiyacının karşılandığı yer olarak değerlendirilebilir. Bu noktada, kullanıcılar tarafından üretilen içeriklerin kapitalist şirketlerin özel mülkiyeti içerisine alınarak değişim ilişkisi içine girdiği ortaya çıkmaktadır.

Kullanıcılarla yapılan görüşmelerde açı̆̆a çıkan bir başka durum, kullanıcıların

63 DY-5 ile yapılan derinlemesine görüşme, 17.04.2020.

64 Marx, Kapital, cilt I, s.49.

65 Karl Marx ve Friedrich Engels, Alman İdeolojisi, çev., Tonguç Ok ve Olcay Geridönmez, İstanbul: Evrensel Basım Yayın, 2013, s.16.

66 Marx ve Engels, Alman İdeolojisi, s.75. 
Twitter'da emeği bir ilişki biçimi olarak değerlendirirken; Twitter’’ sadece bir sosyal medya platformu olarak görmemeleridir.

Twitter'ın aktif halde sürebilmesi için birçok yazılımcı çalışıyor. Bir fabrika gibi çalışan o yerlerde, Twitter’n sürekli dönmesi sağlanıyor. Şikâyetleri dinliyorlar, gönderileri kontrol ediyorlar. Sistemi üretiyorlar. Tekrar tekrar sistemin açıklarına karşı, siber saldırılara karşı sürekli bir çalışma. ${ }^{67}$

DY-4 tarafından vurgulanan çalışma biçimleri, Twitter'ın içerisinde ücretli emekçileri barındıran kapitalist bir şirket olduğuna ilişkin önemli ipuçları sunmaktadır. Burada belirtilmesi gereken en temel durum, Twitter'in tek bir şekilde değerlendirilmesinin sınırlayıcı olacağıdır. Bu anlamda, Twitter iki farklı görünüme sahiptir: (1) Bir mekân ve bir araç olarak Twitter, (2) Kapitalist bir şirket olarak Twitter. Twitter'in her iki görünümünde de kullanıcıları, kullanıcı profillerini ve kullanıcı içeriklerini metalaştıran süreç, ilişki ve biçimler bulunmaktadır. Twitter ve metalaşma süreçleri arasındaki ilişkiyi ele almadan önce, Twitter'ın gelir ve giderlerinin kısaca irdelenmesi önemli görülmektedir.

Katılımcılar, reklam gelirleri ve kişisel bilgilerin satışından elde edilen gelirleri Twitter'ın gelir kaynakları olarak değerlendirmişlerdir. Kaldı ki, Twitter tarafından yapılan açıklamada, 2019 yılının Ekim-Kasım-Aralık aylarını kapsayan dönemde Twitter'ın 1,01 milyar dolar gelir elde ettiği, 2019 yılının son döneminde ulaşılan net kârın ise 119 milyon dolar olduğu belirtilmektedir. Ayrıca, günlük kullanıcı sayısının 152 milyon olduğu ifade edilmektedir. ${ }^{68}$ Twitter Yatırımcı İlişkileri tarafından yayınlanan ilgili raporda, bu dönemde Twitter'ın cirosunun yüzde 11 artış ile 1,01 milyar dolara ulaştığının altı çizilmektedir. Raporda, 2019 yılı toplam gelirinin ise 3,46 milyar dolar olduğu vurgulanmaktadır. ${ }^{69}$ DY-2 ve DY-3 dışındaki tüm katılımcılar Twitter’ın gelirlerini reklamlardan kazandığını söylemiştir. "Benim kitaplarım var. Ben o kitaplarım basıldığı zaman Twitter'da, Facebook'ta, Instagram'da bunların tanıtımına yönelik olarak sponsorlu gönderi ödemesinde bulunuyorum. Daha çok insana ulaşma şansınız var"70 ifadelerinden de anlaşılacağı üzere Twitter, sadece büyük şirketlerin değil sıradan tekil kullanıcıların da reklam verebileceği bir şirket ve o reklamın yayınlandığı bir alandır. Twitter'a verilen reklamlar iki yerde kullanıcının karşısına çıkmaktadır. Birincisi, Twitter'da yer alan gündem sekmesidir. İkincisi ise, her bir kullanıcının zaman akışında karşılaştığı reklam içerikli tweetlerdir.

Twitter'da reklamverenlerin hedef kitlesinin ise Twitter kullanıcıları olduğu anlaşılmaktadır. DG-2 bu durumu, küresel şirketlerle bağ kurarak açıklamaktadır. Yapılan görüşmede DG-2, "Küresel çapta kıyafet üreten şirketler, gıda, ilaç vb. üreten şirketler... Kullanıcılar bunların hedefidir, hedef kitlesidir. Bizler onların müşterisiyiz" ${ }^{11}$

67 DY-4 ile yapılan derinlemesine görüşme, 07.04.2020.

68 Dilara Zengin, “Twitter ilk kez bir çeyrekte 1 milyar dolar gelir elde etti”, Anadolu Ajansı sitesi, 06.02.2020, https://www.aa.com.tr/tr/dunya/twitter-ilk-kez-bir-ceyrekte-1-milyar-dolar-gelir-elde-etti/1726669, (erişim 17.04.2020).

69 Twitter Investor Relations, s. 2 ve 7.

70 DG-1 ile yapılan derinlemesine görüşme, 13.03.2020.

71 DG-2 ile yapılan derinlemesine görüşme, 14.03.2020. 
vurgusunda bulunmaktadır. Bu durum, tersten düşünüldüğünde ise kullanıcıların reklamverenlere Twitter tarafından satıldığı ortaya çıkmaktadır.

Katılımcıların Twitter gelirleriyle ilişkilendirdiği bir diğer durum ise kişisel verilerin satışıdır. DG-2 politika belirlenmesinde kişisel verilerin çok önemli olduğunu vurgularken; DG-5 ise sadece politika yapıcılar için değil, herhangi bir işletme için de önemli olduğunu belirtmektedir: “... kullanıcıların davranış ve tutumlarını, 10 yıl sonra için üretim yapacak kişilere vermek çok büyük bir olay. Yani ben de üretim yapıyorum... İnsanların yönelimini alabileceğim bir veri kaynağına herhalde çok ihtiyaç duyardım."72 Öte yandan, DY-2 ise Twitter platformunun özgün yapısı nedeniyle diğer sosyal medya platformlarından daha fazla bilgi toplama imkânına sahip olduğunu vurgulamaktadır.

Buna ek olarak, Twitter gelirlerine ilişkin beş görüşmeci platformdaki varlıklarının ve çevrimiçi etkinliklerinin bir değer oluşturduğunu ve Twitter'ın bu sayede kâr elde ettiğini ifade etmiştir. DG-2, kullanıcıların Twitter'da varoluşunun Twitter'ı yaratan bir şey olduğunu hatırlatmakta ve "Biz olmazsak, Twitter diye bir şey olmaz"73 açıklamasında bulunmaktadır. Twitter’ kullanan insanların varlığının, Twitter için başat bir öneme sahip olduğuna ilişkin düşünceyi DY-4 ise şöyle aktarmaktadır:

Bir sosyal medya platformunun ayakta kalabilmesi için takipçiye ihtiyacı vardır. O yüzden, içerik üreten kişi hem takipçi olarak oradadır hem de insanların orayı takip etmesini sağlayan, bir unsur olarak içerik üretir. ${ }^{74}$

Özetle, Twitter'da içerik üreten kullanıcılar önce "bir takipçi” olarak orada bulunmaktadır. İçerik üreticilerinde bulunan diğer özellik, başka insanların takipçi olmasını sağlayacak içerikleri üretmeleridir. Benzer olarak, DY-1, insanların olmadığ platformlarda başkalarının da olmayacağını belirtmekte ve çevrimiçi etkinliklerle bu platformlarda insanların var olduğunun altını çizmektedir.

Görüşülen kişilerin Twitter’ın giderleri konusunda iki temel düşüncesi bulunmaktadır. Bunlar, Twitter'ın ücretli çalışanlarına ödenen ücretler ve Twitter tarafından platformun geliştirilmesine harcanan maliyetler olarak sınıflandırılabilir. Twitter'in ücretli çalışanlarının bulunması, bir şirket olarak görünümünün bir parçasıdır. Bununla birlikte kullanıcıları, kullanıcı profillerini ve kullanıcı içeriklerini metalaştırması, reklam süreçlerinin içine dahil etmesi şirket olarak görünümünün diğer parçalarıdır. İkinci durumda yer alan metalaşma süreçleri bir mekân olan Twitter platformunda gerçekleşmektedir ve aynı zamanda, Twitter yaratılan değerlerin aktarımında bir araç haline gelmektedir. Ancak, bu durum Twitter için bir gider olarak karşımıza çıkmamaktadır. Bunun nedeni ise bu durumda emek sürecine dahil olan tarafların ücretlendirilmemesidir.

Altı katılımcı Twitter'ı bir sosyal medya platformunun ötesinde görmekte ve geri planda bulunan ücretli emekçilerin üretim sürecindeki yerine işaret etmektedir.

72 DG-5 ile yapılan derinlemesine görüşme, 23.03.2020.

73 DG-2 ile yapılan derinlemesine görüşme, 14.03.2020.

74 DY-4 ile yapılan derinlemesine görüşme, 07.04.2020. 
DY-4 “Çalışanlara maaş ödüyordur. Yazılımcılarına... Özellikle çağrı merkezleri oluyor böyle yerlerin. Yani, çalışanlarına maaş ödemektir bence Twitter’ın giderleri”75 vurgusunda bulunmaktadır. Katılımcılar tarafından açıklanan ikinci bir gider ise teknolojik yatırımlar, server giderleri, depolama araçları olarak tanımlanmaktadır. DY-1 kendisiyle yapılan görüşmede, sitenin açılması, onun işlevlendirilmesi ve geliştirilmesinin Twitter'ın bir gideri olabileceğinin altını çizmektedir. Bu anlamda, Twitter’ın bir ilk maliyetinin olduğu düşünülmektedir. DG-3 ise "bilgisayarlar ve arşivler için giderler olacaktır”76 vurgusunda bulunmaktadır. Gerçekten de, arşiv giderleri önemli bir noktadır. Dijital verilerin arşivlenmesi, depolanması demek; kullanıcıların etkinliklerinden elde edilen verilerin, kullanıcılardan bağımsız bir şekilde Twitter tarafından depolanmasıdır.

\section{Twitter'da Saptanan Metalaşma Süreçleri}

Katılımcılar, Twitter'ı doğrudan bir meta üretim alanı olarak görmeyen tanımlar yapmaktadır. Örneğin, DY-5 Twitter’ı düşüncelerini rahatça ifade edebildiği bir yer olarak; DG-5 ise, "doğru bilgiye ulaşmak için bir yol” olarak tanımlamaktadır. Dolayısıyla, Twitter'da yer alan metalaşma süreçlerinin gizli bir şekilde yaşandığ gözlemlenirken; kullanıcılarının ve çevrimiçi etkinliklerinin meta haline gelmesinde Twitter ve reklam ilişkisi ön plana çıkmaktadır.

Katılımcıların büyük bölümü çevrimiçi etkinliklerin Twitter’a kazanç sağladığını ileri sürmüşlerdir. Yalnızca iki katılımcı, çevrimiçi etkinliklerin Twitter’a bir kazanç sağlamadığını belirtmiştir. DG-1, kullanıcılar tarafından atılan tweetlerin, yapılan retweet ve beğenilerin reklamverenlere yapılan satışta bir veri haline geldiğini tıklanma sayısı ile ilişki kurarak şöyle açıklamaktadır:

Sonuçta tıklanma oranıyla ilgili. O da bu alanda satın alma yapan kuruluşlara diyor ki, bugün benim platformuma Türkiye'de giren insan sayısı örnek veriyorum 30 milyon. Ankara bölgesinde giren insan sayısı da örneğin 3 milyon. Dolayısıyla, reklamını alırken, o da buna göre yapıyor. ${ }^{77}$

DG-1, Twitter kullanıcılarının etkinliklerinin tıklanma sayısı yarattığı ve yaratılan tıklanma sayısının ise Twitter'da reklam verecek olanlara bir pazarlama unsuru olarak sunulduğunu ifade etmektedir. DY-1 de buna benzer şekilde, yapılan çevrimiçi etkinliklerin kullanıcıların platformda kalmasına olanak sağladığını hatırlatmakta ve bu durumun Twitter’a kazanç sağladığını belirtmektedir.

DG-2 ve DY-4 sadece reklamverenlere satılmasının yanı sıra, kurum ve kuruluşlara satılması yoluyla da çevrimiçi etkinliklerin metalaştı̆̆ını vurgulamaktadır. DG-2, Twitter kullanıcılarının çevrimiçi etkinlikleriyle bir düşünce üretimi yaptığının altını çizmekte ve bu üretimlerin kendisinin de Twitter tarafından kazanca çevrildiğini belirtmektedir. DG-4, kullanıcıların çevrimiçi etkinlilerinin Twitter’a kazanç sağladığını düşünmekle birlikte, bu durumun kullanıcılar tarafından önemsenmediğini

75 DY-4 ile yapılan derinlemesine görüşme, 07.04.2020. 
dile getirmektedir. Benzer şekilde DG-3, Twitter'ın kazanç sağladığını düşünmekte ancak, sağlanan bu kazancı "olması gereken" olarak nitelendirmekte ve olumlamaktadır. Twitter'a reklam vermiş bir katılımcı olan DG-5'in aktardıkları ise Twitter'daki reklam süreçlerinde nelerin etkili olduğuna ilişkin ipuçları sunmaktadır:

Twitter reklam verirken size seçenek sunuyor. Mesela, kaç yaş aralığına hitap etmesi gerektiği ya da profilinde hangi kelimelerin olduğuna yönelik. Kişisel veri derken, örneğin ana adı, baba adı gibi ya da telefon numarası gibi bilgiler değil. Eğilimler ya da bulunduğu meslek grubu... ${ }^{78}$

Twitter profilinde yer alan kişisel bilgilerin yanı sıra, kullanıcıların profilinde hangi kelimeleri kullandığının, mesleğine ilişkin bilgilerin bulundurmasının da reklam içerikli tweet için önemli olduğu anlaşılmaktadır. Gerek kişisel bilgiler gerekse kullanıcılar tarafından yaratılan içeriklerden yapılan kelime analizleri, onları yaratan kullanıcıları bir reklamın hedefi haline getirmektedir. DG-5 tarafından aktarılan süreç ele alındığında, kullanıcıların reklamverenlere satılan bir meta olmalarının yanı sıra, kendini metalaştıracak içeriklerin de üreticileri olduğu ortaya çıkmaktadır. Kullanıcılar tarafından atılan tweetler, yapılan retweet ve beğeniler metalaşarak reklamverenlere bir veri olarak sunulurken; Twitter kullanıcıları kendilerini bir meta olarak üretmektedir.

Öte yandan, kullanıcılar Twitter'da yer alan reklamların hedef kitlesi haline gelmektedir. Hedefli reklamcılık uygulamalarında hedefin daraltılması için gerekli veriler kullanıcıların yarattığı içerikler aracılığıyla elde edilmektedir. Ayrıca, hedefli reklamcılık uygulamalarında ilgili hedefin daraltılması Twitter'da yaratılan kullanıcı içeriklerinin önemini daha da belirginleştirmektedir. Görüşme yapılan sekiz kişi, Twitter'da yer alan reklamların hedefli reklamlar olduğuna işaret etmekte; reklamların kullanıcıya göre farklılık gösterdiğini belirtmektedir. Kullanıcıların hem Twitter'da hem de diğer dijital ortamlarda yaptıkları çevrimiçi etkinlikler reklamların kişiselleşmesinde büyük bir öneme sahiptir. Reklamların kişiselleşmesi konusunda elde edilen bulgular, bu durumun, kullanıcılar tarafından oluşturulan içerikler arac1lığıyla gerçekleştiğini ortaya koymaktadır.

Twitter'daki metalaşma süreçlerinin katmanlı yapısının daha iyi anlaşılması için Twitter'daki reklam süreçlerine de bakılmalıdır. Twitter'ın şirket olarak kâr sağlamadığı bazı süreçler, üçüncü kişilerin Twitter’a değil, bir Twitter kullanıcısına reklam verme pratiklerini kapsamaktadır. Bu süreçler, tekil kullanıcılara bir kazanç elde etme olasılığını sunmakla birlikte, metalaşma süreçlerini daha da derinleştirmektedir. Dokuz görüşmeci, kendi hesaplarını yönetirken kâr beklentilerinin olmadığını vurgulamıştır. Ancak, bu görüşmecilerin yedisi, bu beklenti içinde olan Twitter kullanıcılarının olduğunu söylemiştir. DG-4 ise, diğerlerinin aksine, Twitter'ı kâr beklentisiyle kullandığını vurgulamıştır. DY-2'nin bu konudaki görüşleri aydınlatıcıdır:

Buradan para kazanmaya çalışanlar var. Bu insanların birçoğunun, gerçek hayatta çok bir karşılığı yok. Ancak, sosyal medyada yarattıkları, ürettikleri şey-

78 DG-5 ile yapılan derinlemesine görüşme, 23.03.2020. 
leri normal piyasayla eşleştiriyorlar. Dolayısıyla, buradan bir gelir elde etmeye çalışıyorlar. Bir de, normal hayatın içinde doktorluk yapan, avukatlık yapan, yani sosyal medya üzerinden ünlü olmamış ya da bunun üzerinden daha önce gelir elde etmemiş insanlar var. Buraları, kendileri için bir reklam aracı olarak kullanabiliyorlar. ${ }^{79}$

DY-2, Twitter'ı gelir kazanmak amacıyla kullanan kullanıcıların iki grupta değerlendirilebileceğini söylemektedir: (1) Twitter aracılı̆̆ıyla tanınır olduktan sonra, diğer emek piyasalarına dahil olan ve takipçilerini bu piyasalarda kendi müşterisi olarak gören kullanıcılar, (2) Başka bir emek piyasasında bulunan ve bu piyasalardaki gelirini artırmak amacıyla Twitter vb. ağlarda yer almaya başlayan kullanıcılar. Twitter'daki değer yaratım sürecinin diğer emek piyasalarıyla olan ilişkisi burada açığa çıkmaktadır. Birinci durumda sosyal medya, gelir elde etmek isteyen kullanıcıya "avantaj” sağlamaktadır. İkincisinde ise kullanıcı, "avantaj” sağlama olasılığı/potansiyeli üzerine bu alanlara yönelmektedir. Burada, "avantaj" tanınır olmak ya da tanınır olma potansiyelidir. Tanınırlık ise aktif takipçi sayısı ve takipçilerin girdiği etkileşim ile ilişkilidir. Aktif takipçi olarak ifade edilenlerin Twitter'daki tekil kullanıcılar, etkileşimin ise bu tekil kullanıcıların çevrimiçi etkinlikleri olduğu hatırlanırsa birinci durumda "avantaj", ikinci durumda ise "avantaj potansiyeli" olarak değerlendirilen bu durum; "metalaşmış Twitter kullanıcısı/kullanıcı içeriği" ve "metalaşma potansiyeli bulunan Twitter kullanıısı/kullanıcı içeriği" olarak yeniden kavramsallaştırılmalıdır.

DG-3 işsiz kalan gazeteci bir arkadaşının sosyal medyayı araç olarak kullanması hakkında, "Sosyal medyayı araç olarak kullandı. Ciddi bir takipçisi oldu. Kitap bastı̆̆ı zaman, hazır satış potansiyeli oldu ve karnını buradan doyuruyor" ${ }^{80}$ demiştir. "Hazır satış potansiyeli” ifadesi yakından incelendiğinde; sözü edilen kişinin takipçilerinin metalaşma potansiyeli içinde olduğundan söz edilebilir.

"Satıllı hesaplar" diye sürekli karşımıza çıkan kullanıcılar var. Bu insanlar, ciddi rakamlara hesaplarını, biriktirdikleri o kullanıcı sayısını, takipçi sayısını satıyorlar. Çok fazla olmasa da, böyle bir kitlenin olduğunu söyleyebiliriz. ${ }^{81}$

DY-3 tekil kullanıcılara gelir sağlayan ve "hesap satış" olarak bilinen durumu anlatmaktadır. Bu ifadeleri destekleyecek biçimde belirli bir takipçi sayısıyla birlikte, Twitter hesaplarının satışına ilişkin örnekler bulmak mümkündür. Kaldı ki, sadece hesap satışı yapan internet siteleri de bulunmaktadır. Hesabın bir bütün olarak satılmasıyla, satılan şeyin o hesabın daha önce yaptı̆̆ çevrimiçi etkinliklerin toplamı ve o hesabı takip eden kullanıcılar olduğu saptanmaktadır.

Burada, sosyal medya ünlüsü anlamında fenomenlere de bakmak önem taşımaktadır. Görüşülen dokuz kişi, fenomenlerin Twitter aracıllğıyla para kazandığını ifade etmektedir. Ancak, katılımcılar tarafından dile getirilen ağırlıklı görüş, fenomenlerin kazancını Twitter şirketinden değil üçüncü kişilerden sağladığı yönündedir.

79 DY-2 ile yapılan derinlemesine görüşme, 21.03.2020.

80 DG-3 ile yapılan derinlemesine görüşme, 19.03.2020.

81 DY-3 ile yapılan derinlemesine görüşme, 12.03.2020. 
Fenomenlerin "reklam şirketleri” gibi çalıştığı; Twitter profillerinin reklam panosu gibi işlev gördüğüne yönelik vurgular dikkat çekicidir. Diğer katılımcılar ile benzer düşünceleri paylaşan DG-2, fenomenlerin üçüncü kişilere sattığı şeyin "kendilerini takip edenlerin sayısı" olduğunu söylemektedir.

[Fenomenler]... Özel sektörden kazanıyorlardır. Doğrudan sosyal medyadan değil. Üçüncü kişilerden kazanıyorlardır. Ne kadar çok takipçi kitlesi artarsa, oraya şirketler daha çok reklam verirler. ${ }^{82}$

"Durmadan ... reklamı paylaşmaya başladı. Her indiriminde de mi paylaşırsın yani? Ben onu, normal sponsorlu reklam olarak görmesem bile, takip ettiğim kişiden görmeye başlıyorum". ${ }^{83} \mathrm{Bu}$ açıklamadan da anlaşılacağı üzere, Twitter bir şirket olarak reklam süreçlerine burada dahil değildir. Reklamverenler reklamlarını Twitter'a değil, Twitter kullanıcısına vermektedir. Bu değişime karşın, diğer Twitter kullanıc1larının reklamverenlere satışı ise aynı kalmaktadır. Dolayısıyla, Twitter, Twitter şirketini içermeyen metalaşma süreçlerini de içinde barındıran bir platformdur. Aynı zamanda böylesi bir ilişki biçiminde, kullanıcılar arasında örtük eşitsizlikler doğmaktadır. Takipçiler, takip ettiği hesaplar tarafından reklamverenlere satılan metalar haline gelirken; takipçi sayısının fazlalığının tanıtım süreçlerinde elde edilen gelir artırıcı bir yönünün olup olmadığı da araştırılması gereken bir durum olarak ortaya çıkmaktadır.

Fenomenlerin belirli ilgi alanı olması durumunda, aynı ilgi alanına yönelik üretim yapan firmaların bu kişilere reklam vermesinin özel bir nedeni de reklamverenin hedef kitlesine daha kolay ulaşacağı düşüncesidir. Fenomen, sosyal medya kullanıcıları arasında kendi ilgi alanıyla ilişkili daraltılmış bir takipçi havuzuna sahiptir. Bu durumu DY-2, "Bence şöyle bir algı var reklamcılarda: 'Bu adam yemekle ilgili yazıyor, bunu o zaman yemekle ilgilenen insanlar takip ediyordur’ ..." ${ }^{4}$ şeklinde ifade etmektedir.

Fenomenin kendisi ve fenomenin kullanıcı profili, bütün reklam süreçlerini içine sıkıştıran; ancak, bunu yaparken reklam şirketlerini aradan çıkaran bir aktif özne konumundadır. DY-4, fenomenlerin reklam şirketlerinin yaptığı işleri yerine getiren kişiler olduğuna vurgu yapmaktadır: "Reklam şirketleri gibi çalışıyorlar, yaptıkları işi iletişim ve halkla ilişkiler alanında değerlendiriyorum. Doğrudan reklam ve pazarlama alanı olarak değerlendiriyorum." ${ }^{85}$ Benzer bir düşünceyi DY-2 ise şöyle paylaşmıştır:

Fenomenler, hem pazarlamacı hem reklamın kendisi haline geliyor. Eski düzende, pazarlamacılar farklı bir tarafta duruyordu. Reklamcılar başka bir taraftaydı. Bir ürünün reklamı başka bir yerdeydi. [...] Reklamın hem aktörü oluyor hem de pazarlayıcısı oluyor. Her şeyi haline geliyor. ${ }^{86}$

82 DG-2 ile yapılan derinlemesine görüşme, 14.03.2020. 83 DY-1 ile yapılan derinlemesine görüşme, 17.03.2020. 84 DY-2 ile yapılan derinlemesine görüşme, 21.03.2020. 85 DY-4 ile yapılan derinlemesine görüşme, 07.04.2020. 86 DY-2 ile yapılan derinlemesine görüşme, 21.03.2020. 
Fenomenlerin gelir elde etmesinin ötesinde ortaya çıkan gizil bir durum pek çok emek sürecinin merkezinde yer almalarıdır. Geleneksel reklam süreci içerisinde bulunan pek çok emek süreci fenomenlerin üzerine yıkılırken; reklamverenler bu emek sürecinde yer alan olası maliyetleri en aza indirmektedir. Kaldı ki, reklam içeriklerinin etkisi, Twitter analizleri sayesinde, geleneksel yöntemlere kıyasla daha az maliyetle ölçülmektedir. Bu durumda, reklam şirketi ve yayıncı platform sürecin dışında kalmakta; reklamveren için bu süreçlerde yer alan maliyetler azalmaktadır. Fenomenlerin emeklerine yönelik sömürü bu noktalarda belirginleşmektedir. Twitter'da yer alan pek çok fenomen, çok sayıda reklamverenle bu koşullar altında ilişki kurmaktadır. Oysaki, geleneksel reklam süreçlerinde ücretli emek gücünün mekânsal olarak bir arada olması söz konusudur. Mekânsal bir aradalık, örgütlenme ve dayanışma ilişkileri üzerinde önemlidir. Ayrıca, geleneksel reklam süreçleri içindeki işkollarının sendika deneyimleri de bulunmaktadır. Bu sürecinin merkezinde tek başına sosyal medya fenomeninin kalması; bu süreçlerde emek gücünün güvencesizleştirilmesini ve ucuz işgücüne dönüştürülmesini de beraberinde getirmektedir.

Bakılması gereken son nokta, Twitter başlığında yer alan bilgiler ile kişilerin paylaşımlarının kimler için yarar sağlayan metalar biçimini aldığıdır. Görüşülen sekiz katılımc1, kullanıcıların bütün olarak profilinde yer alan bilgilerin kâr aracı olarak kullanıldığına ilişkin düşünceler öne sürmektedir. Öte yandan, DG-4 ve DY-5, başlıkta yer alan bilgilerin bir kazanç aracı olarak kullanılamayacağını ifade etmektedir. DY-5, değerlendirmesini yaparken kendi profil bilgilerini ve kullanım deneyimlerini temel almıştır. DG-4 ise başlıkta yer alan bilgilerin maddi kazanç sağlamayacağını ifade etmiştir. DY-1, kendisinin bu bilgileri oluştururken herhangi bir kazanç aracı olması amacıyla oluşturmadığını ifade ederken; bu amaçla oluşturulmayan içeriklerin, bu içerikleri tasnifleyerek kâra dönüştürmek isteyen pek çok kişi tarafindan kullanılabileceğini vurgulamıştır.

Benim feminist olduğum çok belli. Çok bariz. Şey var ya işte, girl power şeyleri... Son dönemde yükselen birtakım reklam trendleri var, özellikle reklamları önüme düşürmeye yönelik. Bu reklamlardan daha çok etkilenme ihtimali olan bir hedef kitleyim. Bunun dışında, birtakım şirketlere de bu bilgileri satabileceğini düşünüyorum. Instagram üzerinden, Facebook üzerinden ve daha başka şirketler üzerinden. Daha önce, hiçbir zaman alışveriş yapmadığım ...'dan bana mesaj gelebilir. " 8 Mart'ta ne tişört giyecekler eylemde" diye. ${ }^{87}$

DY-4 de DY-1'e benzer olarak, başkalarının kazanç sağlaması amacıyla kendi içeriklerini oluşturmadığını belirtmekte; ancak, yine de kazanç sağlanabileceğini ifade etmektedir. Kendisini feminist olarak tanımlayan DY-4, yaptığ linden böylesi bir bilginin elde edilebileceğini söylemektedir. Öte yandan, yarattı̆̆ 1 içeriklerin reklamveren şirketlerin hedeflerinin daraltılmasında kolaylık sağladığını da vurgulamaktadir.

Görüşmecilerin temel algıları, bu bilgilerden devletlerin ve şirketlerin yarar sağladıkları yönündedir. Bu bilgilerden yararlanan şirketler iki şekilde karşımıza çıkmak-

87 DY-4 ile yapılan derinlemesine görüşme, 07.04.2020. 
tadır. Birincisi, bu bilgileri sınıflandırarak satan sosyal medya şirketleri; ikincisi ise bu bilgileri özel amaçları için alan şirketlerdir. İlkinde, bu bilgiler metalaşarak diğer şirketlere satılmaktadır. İkincisinde ise meta olarak alınan bu bilgiler, üretilen metanın değerini artıran bir girdi olarak kullanılmaktadır.

\section{Twitter'da Yer Alan Denetim Süreçleri}

Twitter'daki denetim süreçleri ve Twitter içeriklerinin sahiplik durumu irdelenen bu alt başlıkta, denetim süreçleri iki anlamda kullanılmıştır. İlk anlam, Twitter’ın toplumdaki denetim mekanizmalarıyla olan ilişkisine; ikinci anlam ise kullanıcıların yarattığı içerikler üzerindeki denetimine bir başka deyişle, kullanıcıların hesapların varlığı üzerindeki denetimleri (hesabın açılması, kapatılması, engellenmesi vb. hesabın varlığına yönelik) ile kullanıcının içerikleri yaratım sürecindeki özdenetimlerine (içerik oluşturmada gündemin etkisi, belirli bir akış içinde üretme, bağımsızlık problemi vb.) karşılık gelmektedir.

Görüşülen kişilerin tamamı Twitter hesaplarının kontrolünün tamamen kendilerinde olmadığını düşünmektedir. DG-2, DG-3, DY-1 ve DY-5 denetimin sınırlı bir şekilde kendilerinde olduğunu belirtmektedir. DG-1 Twitter'da hiç kimsenin hesap kontrolleri üzerinde denetiminin olamayacağını; DY-3 ise hesap kontrollerinin Twitter ve Facebook gibi platformlarda olduğunu ve bu platformların kendi amaçları doğrultusunda kontrolün biçimini belirlediğini vurgulamaktadır. DG-4 “...mış gibi olduğunu düşünüyorum"88; DG-5 ise "Sosyal medya hesabımın kontrolünün bana bırakıldığını düşünüyorum sadece..." ${ }^{99}$ diyerek hesap kontrolünün kendilerinde olmadığını ifade etmektedir. DY-4 ise şu düşünceyi paylaşmaktadır: "Kontrolün bende olduğunu düşünmek istiyorum ama tam olarak bende değil." ${ }^{90} \mathrm{Bu}$ ifadeler, genel anlamda görüşülen kişilerin kullanıcı hesaplarının varlığı üzerindeki denetimini anlatan düşünceleri yansitmaktadır.

Aynı zamanda hesap üzerinde kullanıcıların özdenetimine yönelik fikirlerinin olduğu da saptanan DY-4 şunları söylemektedir: “Tweeti oranın diline göre atmak gerekiyor. Mesela, yanına hashtag koyacaksın ki anlamı olsun. Orada gündeme girebilmek istiyorsan, gündemden söz eden insanlarla etkileşime geçmek istiyorsan bunlara dikkat ediyorsun." ${ }^{11}$ Twitter'in dili ve Twitter'daki gündem, özdenetimi engelleyen yapılardan bazıları olarak belirginleşmektedir.

Twitter kullanıcılarının Twitter akışına dahil olma biçimi tweet yaratım sürecindeki özdenetim için önemlidir. Twitter, pek çok konunun konuşulduğu bir platform olmakla birlikte, birkaç önemli gündemin -paylaşım yapıldığg anda- yoğun bir şekilde görünür olduğu bir yerdir. Kullanıcılar, belirli bir anda, birkaç konu başlığı hakkındaki çevrimiçi etkinliklere maruz kalan ve/veya bu etkinliklere katılan kimselerden oluşmaktadır. Dolayısıyla, bir gündem hakkında çevrimiçi etkinlikte bulunurken, kullanıcının bunu kendi iradesiyle mi yaptığ 1 yoksa çoğunluk öyle yaptığı için mi

88 DG-4 ile yapılan derinlemesine görüşme, 20.03.2020. 89 DG-5 ile yapılan derinlemesine görüşme, 23.03.2020.

90 DY-4 ile yapılan derinlemesine görüşme, 07.04.2020.

91 DY-4 ile yapılan derinlemesine görüşme, 07.04.2020. 
yaptığ ${ }_{1}$ önemlidir. Bu konu, görüşmecilerin düşüncelerinde de önemli bir yer oluşturmaktadır. Öz denetime ilişkin bu durum DG-1 ve DG-2 ile yapılan görüşmelerde şu ifadelerle görünür kılınmıştır:

Ben gündeme ilişkin şeyler atıyorum. Dolayısıyla, gündemi belirleyen kişi konumunda değilim. [..] Neredeyse her konuyu, gündemle ilişkilendirerek yazıyorum. Dolayısıyla, esas sahibi ben gözükmüyorum. Ben, tırnak içinde fikri mülkiyet içerisinde fikir belirtiyorum. ${ }^{92}$

Hesabımın kontrolü hem bende hem değil. Bende, çünkü kendi irademle yazıp çiziyorum. Bende değil, çünkü ben gündeme göre yorumlarımı yapıyorum, yazıyorum. Orada, gündemi belirleyen ya da gündemi oluşturanlar, benim Twitter hesabımı da bir anlamda yönlendirmiş oluyor. ${ }^{93}$

Twitter gündemi, Twitter kullanıcılarının etkinliklerinin toplamıyla ve o gündeme olan ilgileriyle oluşmaktadır. Twitter'da oluşan gündemin kullanıcı üzerinde mutlak belirleyici etkisi olduğunu düşünmek, Twitter gündemlerinin oluşum sürecinde katılımcıların iradesini belirsizleştirmektedir. Kaldı ki, DG-1 görüşme sırasında Twitter kullanıcılarının gündem üzerinde etkisinin bulunduğunu, "Burası aynı zamanda, gündeme ilişkin bir sürece dahil olma, görüş belirtme yeridir. Dolayısıyla, benim o gündemin gelişmesinin nasıl olması gerektiğine ilişkin belirlememin olduğu katılımcı bir platform" ${ }^{94}$ ifadeleriyle dile getirmektedir. Kaldı ki, Twitter gündemi reel toplumsal yapıda yaşanan çelişkilerden ve Twitter dışı alanlarda oluşan gündemlerden bağımsız değerlendirilmemelidir.

DY-2, Twitter kullanıcısı ve Twitter gündemi arasındaki ilişkiyi değerlendirirken; Twitter'ın retweet özelliğine değinerek bu özelliğin, insanların belirli bir gündeme göre çevrimiçi etkinliğe katılmasında kolaylık sağladığını vurgulamaktadır. Retweet özelliği, insanların Twitter hesabı üzerindeki özdenetimini azaltıcı etkiye sahiptir.

Twitter’ın denetim mekanizmalarıyla ilişkisi derinleştirildiğinde, katılımcılar bu durumu “yakın” olarak tanımlamıştır. DY-2, Twitter ve benzeri platformların mant1ğının insanların düşüncelerini aktarmasına dayalı olduğunu belirtmiş ve Facebook platformuna özgü "ne düşünüyorsun” kalıbını örnek olarak göstermiştir. Twitter’ın paylaşım alanında ise "neler oluyor" ifadesi yer almaktadır. DY-2 tarafından da belirtilen, insanların düşüncelerinin her an bilinebileceğine ilişkin bu kullanım mantığının, Twitter kullanıcılarının denetim mekanizmaları tarafından takip edilmesini kolaylaştırdığ 1 düşünülmektedir. "Saniyesinde” aktarılan bilgiler, yine aynı hızda denetlenebilir bir biçim almaktadır.

Benzer şekilde DG-1, kullanıcıların takiplerinin bu platformlarla kolaylaştığını şöyle belirtmektedir: "Eskiden arkanıza bir tane polis takıyordu. Böylece sizin ne yaptığ1nızı görürdü, şüpheli bir şey varsa işlem yapardı. Şimdi, bazı sözcükleri seçiyorlar

92 DG-1 ile yapılan derinlemesine görüşme, 13.03.2020.

93 DG-2 ile yapılan derinlemesine görüşme, 14.03.2020.

94 DG-1 ile yapılan derinlemesine görüşme, 13.03.2020. 
ve bunları yazanları bana göster diyorlar." ${ }^{95}$ Öte yandan, Twitter ve denetim mekanizmaları ilişkisini DG-4 "sıkı bir ilişki var"; DY-1 ve DY-4 ise "doğrudan bir ilişki var" biçiminde tanımlamaktadır. DY-3, Twitter'ın denetim mekanizmalarıyla olan ilişkisini açıklarken, otoritenin işleyişine zıt durumlarda bu mekanizmaların devreye girebileceğini söylemektedir. Kaldı ki, DY-3’ün, böylesi durumlarda Twitter’’n bu müdahale karşısında herhangi bir direnç göstermeyeceğine yönelik düşüncesi de önemlidir.

Son olarak, yapılan çevrimiçi etkinliklerin sahibinin "kim" olduğuna yönelik katılımcıların düşünceleri irdelenmiştir. Görüşmelerde, Twitter’ın katılımcı yapısının önemli bir unsur olarak görüldüğü saptanmıştır. Twitter’ın katılımcı yapısının görüşülen kişiler üzerindeki etkisi, Twitter içeriklerinin sahibinin "herkes" olduğuna ilişkin bir yaklaşımı beraberinde getirmiştir. Bununla birlikte, DG-2, DG-5 ve DY-2 oluşturdukları Twitter içeriklerini "kendilerine ait" olarak değerlendirmektedir. DY-5 ise oluşturulan içeriklerin sahibinin kim olduğunu tanımlayamayacağını belirtmiştir. İçeriklerin sahibinin kendisi olduğunu düşünmeyen/reddeden katılımc1lar Twitter’n etkileşimli yapısına, kamusal bir mekân olma özelliğine ve kamusal alanda yaşanan olaylara kullanıcıların Twitter üzerinden müdahil olabilmesine vurgu yapmaktadır. İçeriklerin sahibinin kendileri olduğunu söyleyen DG-2, DG-5 ve DY-2 arasındaki ortak özellik ise içeriklerin üretimleri sırasında kendi etkin konumlarını öne çıkarmalarıdır.

Twitter içeriklerini kendilerinin özel mülkiyetinde görmeyi reddeden kullanıcılar, oluşturulan içeriklerin kullanımına ve sahipliğine ortak atamaktadırlar. Kullanıcılar tarafından üretilen ve kullanımına ortaklık atfedilen bu içeriklerin, bazı kimselerin özel metaları haline gelmesi ve bunlardan kâr etmesinin arka planında yatan dinamiği irdelemek bu noktada önemlidir. Bu durum, ilkel birikim süreçleri ile ilişki kurularak açıklanabilir. İlkel birikim, kapitalizmin bu aşamasında da kullandığg birikim yöntemlerinden biridir. İlkel birikim süreçlerinin arka planında yatan temel düşünce, kişilerin meta üreticileri halini almasıdır. İlkel birikim süreçlerinde, insanların meta üreticisi olmak için emek gücü haline gelmesi ifade edilirken zorun rolüne vurgu yapılmaktadır. Zor, burada insanları ücretli emek gücü haline getirecek bir araçtır. Twitter'da da kullanıcıların meta üreticilerine ve ücretsiz emek gücüne dönüştürüldüğü düşünüldüğünde; yaşanılan durum ilkel birikim süreçlerinin ileri bir aşamasıdır denilebilir. Twitter'da bu süreçler örtük olarak sürmektedir. Kaldı ki, zorun karşısında rızayla insanlar buralarda hem var olmakta hem de oluşan metalardan dışlanmaktadır. Kullanıcıların Twitter'da meta ve değer yaratması için Twitter’ı kullanması ve diğer insanlarla etkileşime girmesi gereklidir. Bir başka deyişle, bir metanın üretimi için başka bir metanın kullanım değerine ihtiyaç duyulmaktadır. Bu yönüyle, üretilen metanın değişim değerinden bütünüyle dışlanan kullanıcılar, diğer metaların kullanım değerinden ise yararlanmaktadır. 


\section{Sonuç}

Bu çalışmada sosyal medya kullanıcılarının metalaşması sorunu "izleyici metası" tartışmaları çerçevesinde incelenmiştir. Bu anlamda, görüşme yapılan kişilerin irdelenen kavramlara ilişkin bilinç düzeyinin yüksek olmasında iki durumun etkili olabileceği düşünülmüştür. Birincisi, katılımcıların Kazdağları’ndaki çevre erozyonuna tepki gösteren kimseler olduğudur. İkincisi, katılımcıların eğitim düzeyleridir. Çalışmanın örnek araştırma grubu biri lisans eğitimine devam eden, sekizi lisans eğitimini tamamlamış ve biri yüksek lisans eğitimini tamamlamış görüşmecilerden oluşmuştur. İrdelenen bu iki durumun, ulaşılan sonuçlar üzerinde etkili olduğu düşünülmektedir. Dolayısıyla, çalışmada yapılan genellemelerin 10 kişilik örnek araştırma grubuyla sınırlı olduğu unutulmamalıdır. Kaldı ki, çözümleme ve sonuç bölümünün, örnek grupla yapılan yarı yapılandırılmış görüşmelerden elde edilen bilimsel verilerin çözümlenmesi ve yorumlanmasıyla sınırlı olduğu açıkça ifade edilmelidir.

Çalışmada, Twitter'da yaşanan emek süreçlerinin katılımcılar için ikili bir anlama geldiği sonucuna ulaşılmıştır. Katılımcılar, Twitter'daki emek sürecini hem bir ilişki biçimi olarak hem de emek ve bağlantılı kavramları atılan tweetlerin konusu olması bakımından değerlendirmektedir. Twitter üzerindeki emek süreçlerinden sadece Twitter'ın kâr etmediği anlaşılmaktadır. Twitter dışında yer alan şirketlerin ve tekil kişilerin de Twitter üzerinden kâr ettiği ortaya çıkmaktadır. Twitter’ın ücretlendirilmeyen kullanıcı emeğinin yanı sıra, ücretli emekçileri barındırdığı da anlaşılmaktadır. Böylece, Twitter iki farklı görünüm kazanmaktadır: (1) Mekân ve araç olarak Twitter, (2) Kapitalist bir şirket olarak Twitter.

Twitter’ın gelir ve giderlerine yönelik görüşülen kişilerin yaklaşımları incelendiğinde, reklamlar ve kişisel veri satışı Twitter’ın gelirleri arasında sıralanmaktadır. Bir şirket olarak Twitter’ın gerek tekil kullanıcılardan gerekse şirketlerden reklam ald1ğı saptanmıştır. Bu reklamların hedef kitlesini ise yine Twitter kullanıcıları oluşturmaktadır. Bu iki gelir kalemi dışında, kullanıcılar da Twitter'da izlenirlik/tıklanma oranlarıyla doğru orantılı olarak reklam aracılığıyla gelir sağlamaktadır. Ne var ki, üzerinden kâr sağladığı çevrimiçi içerik üreticilerine Twitter herhangi bir ücretlendirmede bulunmamaktadır.

Twitter kullanıcıları tarafından bu mecra doğrudan bir meta üretim alanı olarak görülmezken, Twitter'da yer alan metalaşma süreçleri örtük olarak devam etmektedir. Twitter'da metalaşan kullanıcıların kendileri, kullanıcıların yarattığı profiller ve kullanıcıların çevrimiçi etkinlikleri olduğu söylenmelidir. Öte yandan, metalaşan kullanıcılar doğrudan bu metaların yaratıcıları olmaktadır. Twitter'da hedefli reklamcıl1ğın ilgisini oluşturan kullanıcılar, Twitter’ın kâr sağlamadığı reklam süreçlerinde de hedef haline gelmektedir. Buna örnek olarak, fenomenlerin reklamverenlerle ilişkisi gösterilebilir. Fenomen hesabın takipçi sayısı ve etkileşim miktarı reklamverenlere satılırken; burada metalaşan takip eden kullanıcılar ve onların çevrimiçi etkinlikleridir. Kaldı ki, fenomen hesabın bir ilgi alanına yönelik olması, o ilgi alanına yönelik reklam vermek isteyenler için de bir avantaj olarak görülmektedir. Bu süreçlerden kazanç sağladığı düşünülen fenomenlerin ise reklam süreçlerinin merkezinde olma- 
sı, güvencesiz çalışma koşullarında bulunması ve ucuz işgücü haline gelmesi söz konusudur. Genel anlamda reklamverenlere satılanlar tıklanma sayısı, etkileşim ve kullanıcı/takipçi olarak karışımıza çıkmaktadır. Bununla birlikte, Twitter hesaplarının bir bütün olarak satıldığı durumlar da söz konusudur. Burada satılan şey Twitter profilindeki takipçi sayısı ve o takipçilerin etkileşim miktarıdır. Bir diğer önemli nokta, kullanıcıların oluşturdukları kişisel bilgilerden ve kullanıcı içeriklerinden elde edilen bilgilerden devlet gibi politika belirleyici yapıların ve şirketlerin kâr etmesidir. Burada kâr eden şirketler ise iki şekilde karşımıza çımmaktadır: (1) Verileri satan sosyal medya şirketleri, (2) Bu bilgileri satın alarak üretim süreçlerine yön veren şirketler.

Görüşülen kişiler, Twitter kullanıcılarının hesapları üzerindeki kontrol hakkında denetimin kullanıcılarda olmadığını ve tweetleri oluşturma aşamasındaki özdenetimin ise Twitter’n yapısındaki bazı özellikler nedeniyle zayıf kaldığını düşünmektedir. Öz denetimin önündeki engeller kullanılan dil, Twitter gündemi ve kullanıcıların akışa katılma biçimleri olarak sıralanabilir. Katılımcılar Twitter ve denetim mekanizmaları arasında "yakın bir ilişki" olduğundan söz etmişlerdir. Görüşülen kişilerin büyük çoğunluğunun Twitter’da yarattıkları içeriklerle "sahiplik" ilişkisi kurmadığı saptanmıştır. Katılımcılar, içeriklerin kullanımının herkese açık olması gerektiğini dile getirirken; içeriklerin kamusal olma niteliğine vurguda bulunmuştur. Öte yandan, kullanıcıların yarattıkları içerikler üzerinde sahiplik ilişkisi kurmamasına karşın, bu içeriklerin metalaşarak belirli kesimlere kâr sağlayan ürünler haline gelmesi ise dikkat çekicidir.

Sosyal medya çağında ilkel birikim süreçlerinin ileri bir aşamasının yaşandığı gözlenirken, kullanıcılar kendi yarattıkları içeriklerden koparılmakta ve içerikleri başkaları tarafından mülk edinilmektedir. Son söz olarak, Twitter ve benzeri mecralarda yer alan metalaşma ve emek süreçlerinin eleştirel ekonomi politik yaklaşımın daha fazla konusu haline gelmesi; sosyal medya çalışmaları alanında yapılacak yeni araştırmalara önemli katkılar sağlayacaktır.

\section{Kaynakça}

Aydoğan, Aylin. "Enformasyon ve İletişim Hizmetleri: Kamusal Faydayı Yeniden Düşünmek". İletişim Ağlarında Yeni Hizmetler. Der., Funda Başaran ve Haluk Geray. Ankara: Ütopya Yayınları, 2016: 8-18.

Boratav, Korkut. Emperyalizm, Sosyalizm ve Türkiye. İstanbul: Yordam Kitap, 2017.

Dağtaş, Erdal ve Mehmet Emir Yıldız. "Türkiye'de 'İzleyicinin Metalaşması': Televizyon Dizilerinin Sosyal Reyting Ölçümlerinin Eleştirel Ekonomi Politik Çözümlemesi. Global Media Journal TR Edition. 5/10 (2015): 120-142.

Eaton, John. Ekonomi Politik-Marksist Bir El Kitabı. Çev., Şiar Yalçın. Ankara: Bilim ve Sosyalizm Yayınları, 1978.

Fine, Ben ve Alfredo Saad-Filho. Marx’ın Kapital'i. Çev., Nail Satligan. İstanbul: Yordam Kitap, 2012.

Foley, Duncan Karl. Kapital'i Anlamak: Marxin İktisat Teorisi. Çev., Hakan Öngel. Ankara: Arkadaş Yayınevi, 2010.

Fuchs, Christian. Dijital Emek ve Karl Marx. Çev., Tahir Emre Kalaycı ve Senem Oğuz. İstanbul: NotaBene Yayınları, 2015. 
Fuchs, Christian. Sosyal Medya: Eleştirel Bir Giriş. Çev., İlker Kalaycı ve Diyar Saraçoğlu. İstanbul: NotaBene Yayınları, 2018.

Geray, Haluk. "Birikim Düzenleri, Yeniden Yapılanma ve Küreselleșme”. İletișim Ağlarının Ekonomisi. Der., Funda Başaran ve Haluk Geray. Ankara: Ütopya Yayınevi, 2016: 42-65.

Geray, Haluk. “Geleneksel Medyada Reklamcılık”. İletişim Ağlarının Ekonomisi. Der., Funda Başaran ve Haluk Geray. Ankara: Ütopya Yayınevi, 2016: 151-168.

Gimenez, Martha E. “Özkaynak Kullanımı: Şirketler Bizi Nasıl Ücret Ödemeden Çalıştırıyor?”. Çă̆daş Marksizm Seçkisi. Çev., Şükrü Alpagut. Der., Bertell Ollman ve Kevin B. Anderson. İstanbul: Yordam Kitap, 2018: 187-192.

Göztepe, Özay. İlkel Birikim ve Acele Kamulaştırma. İstanbul: NotaBene Yayınları, 2018.

Harvey, David. Marx’in Kapitali İçin Klavuz. Çev., Bülent O. Doğan. İstanbul: Metis Yayınları, 2015.

Heinrich, Michael. Kapital’e Giriş. Çev., Koray R. Yılmaz. İstanbul: Yordam Kitap, 2017.

Kaya, Ahmet Raşit. “Türkiye Siyasal Yaşamında 1980’ler Sonrası Gelişmeler ve Medya”. Türkiye'de Kitle İletişimi: Dün, Bugün, Yarın. Der., Korkmaz Alemdar. Ankara: Gazeteciler Cemiyeti Yayınları, 2009: 233-247.

Kaya, Ahmet Raşit. İktidar Yumağı. Ankara: İmge Kitapevi Yayınları, 2016.

Kıyan, Zafer. Metalaştırma ve Direnç: Kapitalizmde Kültürün İkili Üretim Yapısı. Ankara: NotaBene Yayınları, 2016.

Luxemburg, Rosa. Sermaye Birikiminin Tarihsel Koşulları. Çev., Neyyir Kalaycıoğlu. İstanbul: Kaynak Yayınları, 1984.

Luxemburg, Rosa. Sermaye Birikimi. Çev., Tayfun Ertan. İstanbul: Alan Yayıncılık, 1986.

Marx, Karl. Kapital. Cilt 1. Çev., Mehmet Selik ve Nail Satılgan. İstanbul: Yordam Kitap, 2016.

Marx, Karl ve Friedrich Engels. Alman İdeolojisi. Çev., Tonguç Ok ve Olcay Geridönmez. İstanbul: Evrensel Basım Yayın, 2013.

Nikitin, Petr Ivanovich. Ekonomi Politik. Çev., Hamdi Konur. Ankara: Sol Yayınları, 2002.

Prodnik, Jernej. "Sürüp Giden Metalaşma Süreçleri Üzerine Bir Not: İzleyici Metasından Toplumsal Fabrikaya". Marx Geri Döndü: Medya, Meta ve Sermaye Birikimi. Der., Vincent Mosco-Christian Fuchs. Çev., Zafer Kıyan. Türkçe Yay. Der., Funda Başaran. Ankara: NotaBene Yayınevi, 2014: 301-366.

Smythe, Dallas Walker. "Batı Marksizminin Kör Noktası”. Kitle İletişiminin Ekonomi Politiği. Der., Levent Yaylagül. Ankara: Dalbaz Yayıncılık, 2006: 127-172.

Twitter Investor Relations, 2019.

Wittel, Andreas. "Sayısal Marx: Dağıtık Medyanın Ekonomi Politiğine Doğru”. Marx Geri Döndü: Medya, Meta ve Sermaye Birikimi. Der., Vincent Mosco-Christian Fuchs. Çev., Özgün Dinçer. Türkçe Yay. Der., Funda Başaran. Ankara: NotaBene Yayınları, 2014: 389-433.

Zengin, Dilara. “Twitter ilk kez bir çeyrekte 1 milyar dolar gelir elde etti”. Anadolu Ajansı sitesi. 06.02.2020. https://www.aa.com.tr/tr/dunya/twitter-ilk-kez-birceyrekte-1-milyar-dolar-gelir-elde-etti/1726669. (erişim 17.04.2020). 


\title{
Critical Political Economy Analysis of the Commodifacation of Prosumer Labor in the Case of Twitter
}

\author{
ERDAL DAĞTAŞ / CEMGAZI YOLDAŞ
}

\begin{abstract}
Dealing with the commodification processes and exploitation of users who participate in online activities on the social networking site Twitter, this study is based on the critical political economy approach. In this study, in which the rise of social media along with the recent developments in communication technologies was evaluated within the capitalist modes of production and style, the production and consumption relations observed in Twitter were examined. The capitalist relations, processes and forms dominating Twitter have evaluated under the thematic categories of analysis; the determinations made in these categories were obtained from semi-structured in-depth interviews conducted with the chosen research group of 10 participants, by intended sampling technique among Twitter users. It is concluded that Twitter is seen by the participants as a digital space in which production and exchange relations take place and a tool that enables these relations to be actualised.
\end{abstract}

Keywords: Twitter, Prosumer labor, Audience commodity, Commodification processes, Primitive accumulation 